"Surface water mass composition changes captured by cores of Arctic land-fast sea ice"

-revised manuscript submitted to Continental Shelf Research

\title{
Surface water mass composition changes captured by cores of Arctic land-fast sea ice
}

Smith, I.J. ${ }^{1 *}$, Eicken, H. ${ }^{2,3}$, Mahoney, A.R. ${ }^{2}$, Van Hale, R. ${ }^{4}$ Gough, A.J. ${ }^{1}$, Fukamachi, Y. ${ }^{5}$, Jones, J. ${ }^{2}$

Author affiliations:

${ }^{1}$ Department of Physics, University of Otago, P.O. Box 56, Dunedin 9054, New Zealand

${ }^{2}$ Geophysical Institute, University of Alaska Fairbanks, P.O. Box 757320, Fairbanks, AK 99775, USA

${ }^{3}$ International Arctic Research Center, University of Alaska Fairbanks, P.O. Box 757320, Fairbanks, AK 99775, USA

${ }^{4}$ Department of Chemistry, University of Otago, P.O. Box 56, Dunedin 9054, New Zealand

${ }^{5}$ Institute of Low Temperature Science, Hokkaido University, Sapporo, Japan.

* Corresponding author:

Phone: +64-3-479-7755, Fax: +64-3-479-0964

Email: inga.smith@otago.ac.nz

\section{Abstract}

In the Arctic, land-fast sea ice growth can be influenced by fresher water from rivers and residual summer melt. This paper examines a method to reconstruct changes in water masses using oxygen isotope measurements of sea ice cores. To determine changes in sea water isotope composition over the course of the ice growth period, the output of a sea ice thermodynamic model (driven with reanalysis data, observations of snow depth, and freeze- 
"Surface water mass composition changes captured by cores of Arctic land-fast sea ice" -revised manuscript submitted to Continental Shelf Research

up dates) is used along with sea ice oxygen isotope measurements and an isotopic fractionation model. Direct measurements of sea ice growth rates are used to validate the output of the sea ice growth model. It is shown that for sea ice formed during the 2011/2012 ice growth season at Barrow, Alaska, large changes in isotopic composition of the ocean waters were captured by the sea ice isotopic composition. Salinity anomalies in the ocean were also tracked by moored instruments. These data indicate episodic advection of meteoric water, having both lower salinity and lower oxygen isotopic composition, during the winter sea ice growth season. Such advection of meteoric water during winter is surprising, as no surface meltwater and no local river discharge should be occurring at this time of year in that area. How accurately changes in water masses as indicated by oxygen isotope composition can be reconstructed oxygen isotope analysis of sea ice cores is addressed, along with methods/strategies that could be used to further optimize the results. The method described will be useful for winter detection of meteoric water presence in Arctic fast ice regions, which is important for climate studies in a rapidly changing Arctic. Land-fast sea ice effective fractionation coefficients were derived, with a range of $+1.82 \%$ to $+2.52 \%$. Those derived effective fractionation coefficients will be useful for future water mass component proportion calculations. In particular, the equations given can be used to inform choices made when engaging in end member determination for working out the component proportions of water masses.

KEYWORDS: Sea ice formation; oxygen isotope fractionation; Arctic surface water mass changes; Chukchi Sea; land-fast sea ice growth rates 
"Surface water mass composition changes captured by cores of Arctic land-fast sea ice"

-revised manuscript submitted to Continental Shelf Research

\section{INTRODUCTION}

\subsection{The rapidly changing Arctic Ocean}

The Arctic Ocean's summer sea ice cover has been rapidly decreasing in areal coverage in recent years (Cavalieri and Parkinson, 2012), with a predominance of multiyear sea ice giving way to mostly first year sea ice (Comiso, 2012). Sea ice thickness and volume have also been reported to be decreasing (Laxon et al., 2013). Such sea ice changes are particularly pronounced in the Pacific Arctic sector, where reductions in ice volume have been attributed to a combination of ice-albedo feedback (Perovich et al., 2011; Pistone et al., 2014), ice dynamics (Hutchings and Rigor, 2012), and increased heat fluxes through Bering Strait (Woodgate et al., 2010). The impact of these changes on the heat and freshwater budget of the surface ocean, and therefore water masses, in the western Arctic is currently being explored. In coastal regions, such water mass changes can have significant impacts on ice production in polynyas and the land-fast ice regime, both by reducing ice growth rates and through meltback and destabilization of land-fast ice (Mahoney et al., 2007; Jones et al., in prep.). However, we are lacking year-round studies of water mass changes in the regions north of Bering Strait and in the southern Chukchi and Beaufort Seas where potential impacts are greatest.

\subsection{Winter water masses near Barrow, Alaska}

Located at the northern tip of the continental North American landmass, Barrow, Alaska, marks the boundary between the Chukchi and Beaufort Seas (Fig. 1). Existing knowledge of winter Arctic coastal water mass changes in this region is sparse. Oceanographic mooring and 
"Surface water mass composition changes captured by cores of Arctic land-fast sea ice" -revised manuscript submitted to Continental Shelf Research

other data for a full year (1994-1995) reported by Weingartner et al. (2005) showed that the Alaskan Coastal Current (ACC) normally transports water of Pacific origin northeastwards along the coast near Barrow. This current acts in opposition to the prevailing northeasterly winds, which create a semi-persistent polynya at the edge of the land-fast sea ice (Martin et al., 2005; Tamura and Ohshima 2011) that represents an area of rapid ice growth and dense water formation (Weingartner et al., 1998; Winsor and Björk, 2000). When these winds are sufficiently strong and persistent, they can temporarily reverse the surface flow of the ACC and lead to upwelling of North Atlantic Water onto the Chukchi Shelf (Pickart et al., 2011). The hydrographic conditions underneath the growing land-fast ice near Barrow are therefore subject to significant changes at synoptic timescales, which can be seen in year-round mooring data (Weingartner et al., 2005). The nearest major river to Barrow is the Colville River, which enters the Beaufort Sea some $250 \mathrm{~km}$ to the East. The Mead and Kuk Rivers are closer, but the extent to which they are discharging in winter is unknown.

\subsection{Oxygen isotopes as a tracer of meteoric water input}

Oxygen isotopes in sea ice cores have previously been used as a tracer of meteoric water input; for example, $\delta^{18} \mathrm{O}$ in sea ice formed near Arctic estuaries was used to examine the scale of localised fresh water input in the winter (Macdonald et al., 1999; Eicken et al., 2005). In this paper, however, we seek to resolve fine structure signals, far from estuaries that are known to discharge fresh water in winter. In particular, we are interested in variations in cumulative freshwater input from a variety of sources on the water mass trajectory from Bering Strait and along the eastern Chukchi Sea coastline. 
"Surface water mass composition changes captured by cores of Arctic land-fast sea ice" -revised manuscript submitted to Continental Shelf Research

The setting in Arctic coastal land-fast sea ice at Barrow, Alaska, is ideal to evaluate whether such changes in water masses can be resolved in depth-profiles of oxygen isotopes obtained from cores of land-fast sea ice. We further investigate how accurately these changes can be reconstructed, and identify methods that should be used to optimize the resolution and accuracy of the datasets. The approach of determining changes in ocean $\delta^{18} \mathrm{O}$ from sea ice $\delta^{18} \mathrm{O}$ has been previously used at a comparatively coarse scale for drifting Arctic pack ice by Pfirman et al. (2004). Here, we eliminate growth rate effects on fractionation using the latest approach (Smith et al., 2015) and obtain time series at a single location through sampling of land-fast sea ice. We also provide validation data for the method with measurements of sea ice growth rates from a sea ice observatory at Barrow (Druckenmiller et al., 2009) and sampling of ocean $\delta^{18} \mathrm{O}$. In addition, oceanographic mooring time series of salinity give a baseline against which to test this reconstruction against.

The derived effective fractionation coefficients presented in this paper for Arctic first year land-fast sea ice will be useful for studies that rely on isotopic fractionation when trying to work out the component proportions of water masses. Previous Arctic measurements of sea ice effective fractionation coefficients have had a wide range, for example from $1.5 \%$ to $2.7 \%$ (Melling and Moore, 1995), and $2.23 \pm 0.13 \%$ (Macdonald et al., 1999). Studies calculating component proportions of water masses have generally picked a single number for the sea ice effective fractionation coefficient, for example 2.1\%o (Bausch et al., 1995), and $2.6 \%$ (Erwurzel et al., 2001; Bauch et al., 2012; Newton et al., 2013). The range of sea ice effective fractionation coefficients obtained in this paper is consistent with the measurements of Melling and Moore (1995). The equations can therefore be used to inform choices made 
"Surface water mass composition changes captured by cores of Arctic land-fast sea ice" -revised manuscript submitted to Continental Shelf Research

when engaging in end member determination for working out the component proportions of water masses.

\section{Methods}

\subsection{Overview}

To reconstruct ocean oxygen isotope ratios (reported as $\delta^{18} \mathrm{O}$ and denoted $\delta^{18} \mathrm{O}_{\mathrm{w}}$ ), we employ the method outlined in Smith et al. (2015), applied here to Arctic sea ice for the first time. The reconstruction of $\delta^{18} \mathrm{O}_{\mathrm{w}}$ requires measurement of sea ice oxygen isotope values (denoted $\delta^{18} \mathrm{O}_{\mathrm{i}}$ ) from sea ice cores taken late in the sea ice growth season, along with reconstructed effective fractionation coefficients $\left(\varepsilon_{\mathrm{eff}, \mathrm{si}}\right)$. The reconstructed $\delta^{18} \mathrm{O}_{\mathrm{w}}$ values have been obtained using Eq. (1) (Eicken, 1998):

$\delta^{18} \mathrm{O}_{\mathrm{w}}=\delta^{18} \mathrm{O}_{\mathrm{i}}-\varepsilon_{\text {eff, si }}$

To reconstruct $\varepsilon_{\text {eff,si }}$, first the Bitz and Lipscomb (1999) thermodynamic sea ice model was used to calculate sea ice growth rates $\left(v_{\mathrm{i}}\right)$, which required observational data on snow thickness and land-fast sea ice formation dates, along with reanalysis forcing data for the period of sea ice growth. Sea ice growth rates were validated using measurements from a sea ice mass balance station (MBS, Fig. 1). $\varepsilon_{\text {eff,si }}$ values were then calculated from the modelled $v_{\mathrm{i}}$ values using the Smith et al. (2012) and Toyota et al. (2013) adaptations of the Eicken (1998) equations that give $\varepsilon_{\text {eff,si }}$ as a function of $v_{\mathrm{i}}$. Eq.(1) was then used to obtain reconstructed $\delta^{18} \mathrm{O}_{w}$ values using the measured $\delta^{18} \mathrm{O}_{\mathrm{i}}$ values and the reconstructed $\varepsilon_{\text {eff,si }}$ values. Finally, the 
"Surface water mass composition changes captured by cores of Arctic land-fast sea ice" -revised manuscript submitted to Continental Shelf Research

reconstructed $\delta^{18} \mathrm{O}_{\mathrm{w}}$ values were validated with measurements of $\delta^{18} \mathrm{O}_{w}$ for sea water taken at the sea ice cores' locations.

\subsection{Barrow, Alaska observational data collected for simulations}

All $\delta^{18} \mathrm{O}$ measurements presented in this paper are from sea water and level first year landfast sea ice samples collected in April 2012 from two sites on the Chukchi Sea near Barrow, Alaska (Fig. 1). The first site (Core B) was in approximately $6 \mathrm{~m}$ of water at the location of the seasonal MBS deployed as part of the Seasonal Ice Zone Observing Network (SIZONet) The second site (Core C) was in approximately $40 \mathrm{~m}$ of water and was as near as possible to the location of an under-ice mooring (B1) that had been deployed as part of SIZONet. Examination of the ice cores showed that the sea ice was predominantly composed of columnar ice below a surface layer of granular and mixed granular/columnar ice of 0.2-0.3 m thickness. The data were used to reconstruct the ocean $\delta^{18} \mathrm{O}$ values and to validate the reconstruction.

\subsubsection{Snow depths}

Reanalysis data sets are known to have issues with accurately representing snow depth, so in order to scale the snow depths, snow accumulation was measured with a ruler at the Core B site on 2 April 2012 and at the Core C site on 6 April 2012. The MBS also provided a time series of snow depth. 
"Surface water mass composition changes captured by cores of Arctic land-fast sea ice"

-revised manuscript submitted to Continental Shelf Research

\subsubsection{Freeze-up dates}

Land-fast sea ice in coastal areas may break out several times in its early growth history before stabilizing and persisting for the remainder of the season. The date that a persistent sea ice cover first formed and remained land-fast until the sampling date is referred to here as the "freeze-up date" for a site. A feasible range of freeze-up dates for the Core B site was determined from times series of webcam images taken of the land-fast sea ice. For the Core C site, a combination of coastal sea ice radar information (http://seaice.alaska.edu/gi/data/barrow_radar) and daily sea ice observations by an Iñupiaq ice expert (Leavitt et al., 2013) were used to narrow down the freeze-up dates.

\subsubsection{Measurements of sea ice growth rates}

Sea ice growth rates, $v_{\mathrm{i}}$, derived from thermistor string measurements for 2012 were used to validate the application of the Bitz and Lipscomb (1999) model. The 2012 SIZONet sea ice MBS was located at the Core B site. Full metadata and datasets for the SIZONet MBS are archived at: http://seaice.alaska.edu/gi/data/barrow_massbalance (last viewed 7 June 2014) and the Advanced Cooperative Arctic Data and Information Service (Eicken et al., 2009 (updated 2012)). Growth rates were determined by dividing the thermistor spacings $(0.1 \mathrm{~m})$ by the difference in freeze-in times between adjacent thermistors. Freeze-in times were determined using the method of Smith et al. (2012). Growth rates based on this method compared well with those from an upward-looking acoustic altimeter deployed at the MBS location (Benthos PSA-916), used to determine ice thickness. 
"Surface water mass composition changes captured by cores of Arctic land-fast sea ice"

-revised manuscript submitted to Continental Shelf Research

\subsubsection{Sampling for oxygen isotope analysis}

Oxygen isotope analysis results from one sea ice core ("sample") taken at each of the sites are presented in this paper. Each core was cut into $0.05 \mathrm{~m}$ sections (“sub-samples"). Sub-samples from 0-0.15 $\mathrm{m}$ depth were excluded from the analysis because the upper layer of granular ice, mostly derived from frazil, was not representative of early season congelation ice growth. Sub-samples were melted inside pairs of plastic bags, and aliquots decanted into glass bottles. Salinity was also measured with a conductivity probe for each melted sub-sample in the bags immediately after decanting.

To obtain a set of $\delta^{18} \mathrm{O}_{\mathrm{w}}$ measurements for validation purposes, surface sea water samples $(n=4)$ for isotope measurements were taken with a stoppered polyethylene bottle submerged on a rod for sites B and C on 4 and 6 April 2012, respectively, and poured into glass bottles. Sea water samples were taken at depths of $2.3 \mathrm{~m}$, which corresponds to approximately $1 \mathrm{~m}$ below the bottom of the sea ice ( $0.8 \mathrm{~m}$ for the Core $\mathrm{B}$ site, and $1.3 \mathrm{~m}$ for the Core $\mathrm{C}$ site). The ocean was accessed through $15 \mathrm{~cm}$ diameter core holes, where $9 \mathrm{~cm}$ diameter cores had been extracted.

\subsubsection{Analysis of oxygen isotope ratios}

Oxygen isotope analysis was carried out at the University of Otago Department of Chemistry, as described in Toyota et al. (2013). Mean precisions (the repeatability of a measurement on a single sub-sample) for Core $\mathrm{B}$ and Core $\mathrm{C} \delta^{18} \mathrm{O}_{\mathrm{i}}$ for sea ice sub-samples were $\pm 0.05 \%$ and $\pm 0.06 \%$, respectively. Mean precisions for $\delta^{18} \mathrm{O}_{\mathrm{w}}$ for sea water sub-samples taken at the Core B and Core C sea sites were both $\pm 0.06 \%$. 
"Surface water mass composition changes captured by cores of Arctic land-fast sea ice"

-revised manuscript submitted to Continental Shelf Research

\subsubsection{Ocean salinity data}

Although not needed for the $\delta^{18} \mathrm{O}_{\mathrm{w}}$ reconstructions, salinity data can potentially offer additional information on water masses. Two year-round under ice moorings (nearshore site B1 (water depth $41.5 \mathrm{~m}$ ) and offshore site B2 (water depth $51.6 \mathrm{~m}$ ) in Fig. 1) were deployed in August 2011 as part of SIZONet. Each mooring had a Seabird SBE 37 temperature and conductivity recorder located below an ASL IPS5 ice profiling sonar (IPS), which included a pressure sensor. Each mooring also included an acoustic Doppler current profiler (ADCP) to measure ocean current velocities (data archived at: https://www.aoncadis.org/dataset/mooring_adcp_data.html). The nominal depths of each ADCP was approximately $7.3 \mathrm{~m}$ above the sea floor, so for the nearshore mooring, the nominal ADCP depth was $34.2 \mathrm{~m}$ and for the offshore mooring, the nominal ADCP depth was $44.3 \mathrm{~m}$. Salinity is calculated from conductivity, temperature and depth. Derived time series of salinity were calculated using the SBE 37 conductivity measurements, the SBE 37 temperature measurements, and depth data which were obtained by interpolating the iceprofiling sonar depth measurements to the position of the $\mathrm{CT}$ recorder based on the mooring configuration of the moorings B1 and B2, respectively (Fukamachi et al., 2011 (updated 2014); Eicken et al., 2011 (updated 2014)). The minimum, mean, and maximum depths of the B1 sensors were $29.5 \mathrm{~m}, 30.2 \mathrm{~m}$, and $34.6 \mathrm{~m}$, respectively. The B2 conductivity and temperature mooring data have gaps at times, and are therefore not analysed in this paper. In addition, sea water salinity at the Core B site was measured on 10 April 2012 and 12 April 2012 with a YSI 30 conductivity salinity temperature probe. On 10 April, the probe was lowered directly through a core hole drilled in the sea ice. To exclude the possibility of ice crystals causing a spuriously low salinity, the measurement was repeated on 12 April in a 
"Surface water mass composition changes captured by cores of Arctic land-fast sea ice" -revised manuscript submitted to Continental Shelf Research

laboratory in Barrow using a water sample that was collected with a Niskin bottle deployed through a larger hole in the ice.

\subsection{Simulation methods}

\subsubsection{Sea ice growth rate calculations from reanalysis data}

Sea ice growth rates were calculated using a one dimensional thermodynamic scheme from Bitz and Lipscomb (1999) (denoted BL99 from here on), forced with NASA MERRA reanalysis $0.25^{\circ}$ daily output (Rienecker et al., 2011) from the grid point nearest each site. The six reanalysis variables used were downward shortwave and longwave radiation at the surface; sensible and latent heat flux; surface snowfall; and fraction of sea ice. The BL99 model default Arctic multiyear ice salinity parameters of $3.2 \mathrm{ppt}$ maximum and $1.0 \mathrm{ppt}$ minimum salinity were modified to represent first year Arctic fast ice by setting the sea ice salinity to $12 \mathrm{ppt}$ maximum, $5 \mathrm{ppt}$ minimum, and $6 \mathrm{ppt}$ end value (i.e., the bottom of the core).

Calculations were performed with an ocean-to-ice heat flux $F_{\mathrm{w}}=2 \mathrm{~W} \mathrm{~m}{ }^{-2}$ for all runs. A constant ocean heat flux of $F_{\mathrm{w}}=2 \mathrm{~W} \mathrm{~m}^{-2}$ is based on Maykut and Untersteiner (1971), and is the default value used in BL99. A constant value of $F_{\mathrm{w}}=4.5 \mathrm{~W} \mathrm{~m}^{-2}$, based on the empirically calibrated Chukchi Sea value from Vancoppenolle et al. (2007), was also tried, but this gave a final ice thickness that was less than the measured value. In the absence of published data on short-term variation in ocean to ice heat transfer, we could not justify the use of a timevarying flux. 
"Surface water mass composition changes captured by cores of Arctic land-fast sea ice"

-revised manuscript submitted to Continental Shelf Research

The major uncertainty in correctly simulating land-fast sea ice growth arises from poor knowledge of (i) a site's snow accumulation history and (ii) the freeze-up date. To address (i), the measured total snow accumulation when the sea ice was sampled at the end of the observations was used to determine a range of likely snow accumulation histories by scaling the reported MERRA precipitation field to reproduce $80 \%, 90 \%, 100 \%, 110 \%$ and $120 \%$ of the measured total. To address (ii), a feasible range of freeze-up dates for the Core B and Core $\mathrm{C}$ sites was determined as described earlier. Simulations were then performed using every combination of start date and scaling of the snow accumulation history. This resulted in a range of possible growth rate histories for each sub-sample (layer) of the sea ice.

\subsubsection{Sea ice effective fractionation coefficient calculations}

For each sub-sample, the sea ice growth rates, $v_{\mathrm{i}}$, calculated using BL99 were used to calculate the sub-sample's expected range of effective fractionation coefficients for sea ice, $\varepsilon_{\text {eff,si. }}$. For low growth rates, $v_{\mathrm{i}}<2.0 \times 10^{-7} \mathrm{~m} \mathrm{~s}^{-1}$, see Toyota et al. (2013) for the physical reasons for this choice, $\varepsilon_{\text {eff,si }}$ was calculated using Eicken's (1998) equation (22) with a growth velocity offset $\left(-4.6278 \times 10^{-8} \mathrm{~m} \mathrm{~s}^{-1}\right)$ as applied by Smith et al. (2012). For high growth rates $\left(v_{\mathrm{i}} \geq 2.0 \times 10^{-7} \mathrm{~m} \mathrm{~s}^{-1}\right), \varepsilon_{\text {eff,si }}$ was calculated using Toyota et al. (2013) equation (9). These equations are expressed below as Eq. (2), for $v_{\mathrm{i}}$ in units of $\mathrm{m} \mathrm{s}^{-1}$ :

$$
\varepsilon_{\text {eff, si }}=a_{1}+a_{2} \exp \left(a_{3}\left(v_{\mathrm{i}}+a_{4}\right)\right)+a_{5} \exp \left(a_{6}\left(v_{\mathrm{i}}+a_{4}\right)\right)
$$

where for $v_{\mathrm{i}}<2.0 \times 10^{-7} \mathrm{~m} \mathrm{~s}^{-1}$ :

$$
\begin{aligned}
& \mathrm{a}_{1}=-7.8328 \times 10^{-3} \%, \mathrm{a}_{2}=2.2416 \%, \mathrm{a}_{3}=-1.3692 \times 10^{6} \mathrm{~s} \mathrm{~m}^{-1}, \mathrm{a}_{4}=-4.6278 \times 10^{-8} \mathrm{~m} \mathrm{~s}^{-1}, \mathrm{a}_{5}= \\
& 0.4918 \%, \mathrm{a}_{6}=-2.9447 \times 10^{7} \mathrm{~s} \mathrm{~m}^{-1} ;
\end{aligned}
$$


"Surface water mass composition changes captured by cores of Arctic land-fast sea ice" -revised manuscript submitted to Continental Shelf Research

and for $v_{\mathrm{i}} \geq 2.0 \times 10^{-7} \mathrm{~m} \mathrm{~s}^{-1}$ :

$\mathrm{a}_{1}=1.2280 \%, \mathrm{a}_{2}=0.7311 \% 0, \mathrm{a}_{3}=-1.2484 \times 10^{7} \mathrm{~s} \mathrm{~m}^{-1}, \mathrm{a}_{4}=0 \mathrm{~m} \mathrm{~s}^{-1}, \mathrm{a}_{5}=0.8441 \% 0, \mathrm{a}_{6}=$ $-1.2821 \mathrm{~s} \mathrm{~m}^{-1}$.

Previous papers, such as Eicken (1998), have not included an uncertainty associated with the equations for determining $\varepsilon_{\mathrm{eff}, \mathrm{si}}$ from $v_{\mathrm{i}}$. It is beyond scope of this paper to quantify the uncertainties for such equations. Eq. (2) is therefore treated as if the only uncertainties arise from the values of $v_{\mathrm{i}}$ used, and not from any inherent uncertainties in the equation itself.

2.4 Combining sea ice $\delta^{18} \mathrm{O}_{\mathrm{i}}$ measurements with simulations to calculate sea water $\delta^{18} \mathrm{O}_{\mathrm{w}}$ The derived effective fractionation coefficients for sea ice, $\varepsilon_{\mathrm{eff}, \mathrm{s}}$, were then used in conjunction with the measurements of $\delta^{18} \mathrm{O}_{\mathrm{i}}$ to calculate the $\delta^{18} \mathrm{O}_{\mathrm{w}}$ values for surface sea water using Eq. (1).

\section{Results}

The snow accumulation at the Core B site on 2 April 2012 was measured to be 0.17 to $0.21 \mathrm{~m}$, so an intermediate value of $0.19 \mathrm{~m}$ was used in the simulations. The snow accumulation at the Core C site on 6 April 2012 was fairly uniform and was measured to be $0.035 \mathrm{~m}$. Total sea ice thickness at these sites on those dates was $1.55 \mathrm{~m}$ and $1.07 \mathrm{~m}$, respectively. 
"Surface water mass composition changes captured by cores of Arctic land-fast sea ice"

-revised manuscript submitted to Continental Shelf Research

For the Core B site, the probable freeze-up dates inferred from the webcam images taken in Barrow were 14,15 or 16 November 2011. For the Core $\mathrm{C}$ site, the probable freeze-up dates obtained from the radar and sea ice observer data were 8, 9, or 10 February 2012. The simulations used each of these dates, to cover the range of possibilities.

Sea ice growth rates calculated using the BL99 model for Core B (Fig. 2a) indicate a decrease from approximately $2 \mathrm{~cm}$ per day early in the growth season to a fairly steady growth rate of approximately $0.7 \mathrm{~cm}$ per day at the time the sea ice core was extracted. An increase in the growth rate and subsequent decrease when the sea ice was approximately $1 \mathrm{~m}$ thick is supported by the growth rate measurements $(n=6)$ from the thermistor string at the site. There is overall qualitative agreement between the BL99 model calculations of the growth rates and the validation measurements, and quantitative agreement of the final sea ice thickness. The depth offset of approximately $0.1 \mathrm{~m}$ between when modeled growth rates decrease or increase and when the measurements decrease or increase is an artifact of the assumption of constant $2 \mathrm{~W} \mathrm{~m}^{-2}$ ocean heat flux. Adjusting the assumption to constant $0 \mathrm{~W} \mathrm{~m}^{-2}$ (not shown), for example, improves the depth offset, but worsens the agreement for values of growth rate. For Core $\mathrm{C}$ (Fig. $2 \mathrm{~b}$ ), the sea ice growth rates decrease from approximately $2 \mathrm{~cm}$ per day early on to approximately $1 \mathrm{~cm}$ per day when the core was extracted. For the Core $\mathrm{C}$ site, there were no validation measurements of growth rates available. The results of the BL99 model for the nearshore Core C site (water depth approximately $40 \mathrm{~m}$ ) are assumed to be reliable. It should be noted that the the validation of BL99 could only be carried out for the coastal Core B site (water depth approximately $6 \mathrm{~m}$ ), and that this difference in regime cannot be taken into account using the available data. 
"Surface water mass composition changes captured by cores of Arctic land-fast sea ice" -revised manuscript submitted to Continental Shelf Research

Salinity measurements for Core B sub-samples from $0.15 \mathrm{~m}$ to $1.40 \mathrm{~m}$ had a mean value of $5.2 \mathrm{ppt}$ (excluding the top and bottom $0.15 \mathrm{~m}$ of each core), with a maximum salinity of $13.3 \mathrm{ppt}(0.05$ to $0.10 \mathrm{~m})$ and a minimum of $4.2 \mathrm{ppt}$ (Fig. 3a). For Core C, mean salinity for the sub-samples from $0.15 \mathrm{~m}$ to $0.95 \mathrm{~m}$ was $6.3 \mathrm{ppt}$, with a maximum salinity of $11.2 \mathrm{ppt}(0$ to $0.05 \mathrm{~m}$ ) and a minimum of $5.3 \mathrm{ppt}$ (Fig. 3a). This supports the change made in salinity when using BL99 from the default Arctic multi-year ice salinity parameters (see section 2.3.1).

For Core $\mathrm{B}, \delta^{18} \mathrm{O}_{\mathrm{i}}$ values varied between $-1.11 \%$ and $+0.43 \%$, with the lowest values near the top and bottom of the core, so that the profile with depth is approximately reverse-C shaped (Fig. 3b and Table 1a), but with oscillations in values throughout the core. For Core $\mathrm{C}, \delta^{18} \mathrm{O}_{\mathrm{i}}$ values varied between $-1.57 \%$ and $+0.06 \%$, with a profile similar shaped to that of Core B (Fig. 3b and Table 1b).

The ranges of derived effective fractionation coefficients, $\varepsilon_{\mathrm{eff}, \mathrm{si}}$, were $1.85 \%$ to $2.52 \%$ for Core B (Table 1a), and $1.82 \%$ to $2.17 \%$ for Core C (Table 1b), and the means (excluding the top $0.15 \mathrm{~m}$ and bottom $\sim 0.05 \mathrm{~m}$ due to ice structure and partial formation, respectively) were $2.13 \%$ for Core B and $1.92 \%$ for Core C.

The reconstructed $\delta^{18} \mathrm{O}_{\mathrm{w}}$ values range from $-3.51 \pm 0.12 \%$ to $-1.71 \pm 0.09 \%$ for the Core $\mathrm{B}$ site, and from $-3.70 \pm 0.11 \%$ to $-1.84 \pm 0.07 \%$ for the Core $\mathrm{C}$ site (Fig. 4 and Table 2 ). There are at least four oscillations in reconstructed $\delta^{18} \mathrm{O}_{\mathrm{w}}$ values observable for Core B (Fig. 4 and Table 2). The reconstructed $\delta^{18} \mathrm{O}_{w}$ values for Core $\mathrm{C}$ also exhibit oscillations, with one that appears to be synchronous with an oscillation in $\delta^{18} \mathrm{O}_{\mathrm{w}}$ values for Core B but exhibits greater amplitude in March 2012 (Fig. 4 and Table 2). Although Tables $1 \mathrm{~b}$ and $2 \mathrm{~b}$ list the 
"Surface water mass composition changes captured by cores of Arctic land-fast sea ice" -revised manuscript submitted to Continental Shelf Research

values for Core $\mathrm{C}$ at depths 1.05-1.07, those measurements have been excluded from Fig. 4 and subsequent analysis because the section is so short and partially formed. The height of each box indicates the maximum and minimum limits on each reconstructed $\delta^{18} \mathrm{O}_{\mathrm{w}}$ value by taking into account the precision on sea ice isotope values, and the uncertainty in the modelled sea ice growth rates (Fig. 4). The width of each box indicates the range of times associated with each reconstructed $\delta^{18} \mathrm{O}_{\mathrm{w}}$ value, which is also a function of ice growth rate uncertainty. The boxes widen as time progresses due to the increase in sea ice thickness uncertainty as the growth rates are progressively integrated over time. It can be seen in Fig. 4 that the reconstructed sea water $\delta^{18} \mathrm{O}_{\mathrm{w}}$ values (boxes) for both the Core B site and the Core $\mathrm{C}$ site are very close to the $\delta^{18} \mathrm{O}_{\mathrm{w}}$ values measured (circles) when the cores were taken. Those values are:

$\delta^{18} \mathrm{O}_{\mathrm{w}}$ (measured, core B site 4 April 2012)=-3.56 $\pm 0.06 \%$ $\delta^{18} \mathrm{O}_{\mathrm{w}}$ (reconstructed, core B site, 3 April 2012 ( \pm 9.4 days so range of 24 March to 13 April 2012)) $=-3.51 \pm 0.12 \%$ $\delta^{18} \mathrm{O}_{\mathrm{w}}($ measured, core $\mathrm{C}$ site, 6 April 2012) $=-3.51 \pm 0.06 \%$ $\delta^{18} \mathrm{O}_{\mathrm{w}}$ (reconstructed, core $\mathrm{C}$ site, 4 April 2012 ( \pm 3.9 days so range of 31 March to 8 April 2012)) $=-3.49 \pm 0.09 \%$

Therefore, the method for reconstructing $\delta^{18} \mathrm{O}_{\mathrm{w}}$ gives values that are in agreement with measurements from both cores, within the uncertainties. Hence, the reconstruction gave $\delta^{18} \mathrm{O}_{\mathrm{w}}$ values that were at worst approximately $\pm 0.2 \%$ from the measured values, based on the upper end of the range for reconstructed value and lower end of the range for the measured value for Core B site. 
"Surface water mass composition changes captured by cores of Arctic land-fast sea ice"

-revised manuscript submitted to Continental Shelf Research

Ocean salinity measurements made using the YSI 30 probe in early April indicated low salinity (29.2 $\pm 0.1 \mathrm{ppt}$ for Core B site, not measured for Core $\mathrm{C}$ site) and low $\delta^{18} \mathrm{O}_{\mathrm{w}}$ values were also measured (see above). Ocean salinity at the B1 mooring site oscillated over the period of interest, with lows sometimes below 30 and highs sometimes above 33 (red line in Fig. 5). A five-day running mean shows that some of these oscillations were persistent in time (black line in Fig. 5).

Current rose plots indicate that for mooring B1, currents were predominantly alongshore whereas for mooring B2 current directions were more variable (Fig. 6). The length of the arrows in Fig. 6 indicate the current velocity in the alongshore direction over the period 1 November 2011 - 30 April 2012 for the B1 mooring was approximately 25 to $35 \mathrm{~cm} \mathrm{~s}^{-1}$. The red polygons in Fig. 6 indicate the relative frequency of currents in each direction, which was $30 \%$ north-eastwards and 30\% south-westwards for the B1 mooring. For mooring B2, currents still had an alongshore component of $20 \%$ north-eastwards with current speeds of $20 \mathrm{~cm} \mathrm{~s}^{-1}$, but also a much stronger component away from the shore (20\% westwards, at $30 \mathrm{~cm} \mathrm{~s}^{-1}$ ). Current speed and direction timeseries show that for the B1 mooring (Fig. 7a), current speeds declined after early February to around approximately $10 \mathrm{~cm} \mathrm{~s}^{-1}$, with directions switching between north-eastwards and south-westwards flow in that period. Mooring B2 also measured a decrease in current speeds in early February, with directions switching between north-eastwards and westwards, but then recorded more variable current speeds from early March onwards with direction becoming predominantly westwards (Fig. $7 b)$. 
"Surface water mass composition changes captured by cores of Arctic land-fast sea ice" -revised manuscript submitted to Continental Shelf Research

\section{Discussion}

\subsection{Validation of water mass signal detection method}

Although the sea ice growth rate validation measurements indicate that overall the BL99 model has accurately calculated the growth rates, the first validated growth rate is an overestimate while the second is an underestimate (Fig. 2). This is most likely to be due to uncertainties in the ocean-to-ice heat flux, $F_{\mathrm{w}}$, which has been assumed to be constant at $2 \mathrm{~W} \mathrm{~m}^{-2}$. Analysis (not shown) of the thermistor data to calculate ocean heat fluxes using the residual method (see Smith et al., 2012 for an example) indicated that the overestimate in the first validated growth rate calculation is due to the real value of $F_{\mathrm{w}}$ during that period being greater than the assumed value of $2 \mathrm{~W} \mathrm{~m}^{-2}$, reducing the observed relative to the simulated sea ice growth rate. Conversely, the underestimate in the second validated growth rate calculation is due to $F_{\mathrm{w}}$ being less than $2 \mathrm{~W} \mathrm{~m}^{-2}$ in that period. Smith et al. (2015) highlighted the lack of detailed knowledge of ocean heat flux values as a barrier to the approach used here which relies entirely on retrospective analysis (i.e., requiring only measurements of sea ice $\delta^{18} \mathrm{O}$ from a core taken at a particular time, snow depth when the core was taken, and estimates of freeze-up dates). However, the overall ice thickness obtained is accurate, and the validation shows that the calculated growth rates are in reasonable agreement with measurements.

The oscillations within the approximately reverse-C shaped $\delta^{18} \mathrm{O}_{\mathrm{i}}$ profiles with depth for Cores B and C (Fig. 3b) are interesting because oscillations can be due to changes in the parent water mass $\delta^{18} \mathrm{O}_{\mathrm{w}}$ values, and to changes in sea ice growth rate. Higher growth rates 
"Surface water mass composition changes captured by cores of Arctic land-fast sea ice"

-revised manuscript submitted to Continental Shelf Research

result in lower fractionation, and vice versa with the slowest (i.e., near equilibrium) sea ice growth resulting in the highest fractionation (effective fractionation coefficients of up to $2.7 \%$ (Eicken et al., 1998)). This relationship is quantified in Equation 2. Removing the effects of variations in sea ice growth rate therefore allows determination of the effects of changes in $\delta^{18} \mathrm{O}_{\mathrm{w}}$ on ice isotopic composition. This goal has been achieved by determining derived effective fractionation coefficients, $\varepsilon_{\mathrm{eff}, \mathrm{si}}$, which ranged from $1.85 \%$ to $2.52 \%$ for Core B (Table 1a), and $1.82 \%$ to $2.17 \%$ for Core C (Table $1 \mathrm{~b}: 1.82 \%$ to $2.06 \%$ if the bottom, partially formed part of Core C is included). When Eq. (1) is applied, the result is the reconstructed $\delta^{18} \mathrm{O}_{\mathrm{w}}$ values given in Fig. 4 and Table 2. The oscillations in reconstructed $\delta^{18} \mathrm{O}_{\mathrm{w}}$ values observable for Cores B and C (Fig. 4 and Table 2) therefore indicate that significant changes in water mass oxygen isotope composition took place over this period. Validation of the reconstructed $\delta^{18} \mathrm{O}_{\mathrm{w}}$ values with measured values gave agreement within the uncertainties, and it can be concluded that the reconstruction gave $\delta^{18} \mathrm{O}_{\mathrm{w}}$ values that were at worst approximately $\pm 0.2 \%$ from the measured values. The validation of reconstructed $\delta^{18} \mathrm{O}_{\mathrm{w}}$ with measured values therefore gives us confidence that the wide range of reconstructed $\delta^{18} \mathrm{O}_{\mathrm{w}}$ values for the Core B and Core $\mathrm{C}$ sites shown in Fig. 4 (1.8 \%o and $1.9 \%$ \% respectively, not including uncertainties), are oscillations in water mass composition and can be detected even for a worst case resolution of our method (i.e., $\pm 0.2 \%$ ). This is different from the Antarctic case reported by Smith et al. (2015); although the uncertainty of the reconstructed ocean $\delta^{18} \mathrm{O}_{\mathrm{w}}$ values $( \pm 0.2 \%$ ) was the same here, the range (including uncertainties) of reconstructed $\delta^{18} \mathrm{O}_{\mathrm{w}}$ was only $0.5 \%$, precluding the detection of any seasonal variations. 
"Surface water mass composition changes captured by cores of Arctic land-fast sea ice"

-revised manuscript submitted to Continental Shelf Research

It is also worth noting that the effective fractionation coefficients, $\varepsilon_{\mathrm{eff}, \mathrm{si}}$, for Core B have much the same lower bound ( $1.85 \%$ ) but a higher upper bound and a higher mean $(2.52 \%$ and $2.13 \%$, respectively: Table 1a) than that reported by Smith et al. (2015) using the same method for Antarctic sea ice, where a range of $1.84 \%$ to $2.21 \%$, and a mean of $1.99 \%$ were reported. Core $\mathrm{C}$, on the other hand, has a lower upper bound $(2.06 \%$; and a slightly lower lower bound: $1.82 \%$ : Table $1 \mathrm{~b})$, and a lower mean (1.92\%: Table $1 \mathrm{~b})$ than that reported by Smith et al. (2015). Based on Arctic field measurements, Pfirman et al. (2004) found fractionation by approximately $2 \%$ to be typical of Arctic sea ice growth; the Core B and Core $\mathrm{C}$ results are consistent with and further validate that estimate (in addition to the results of Smith et al. (2015)). Since Core C was taken in thinner and younger sea ice than Core B, and assuming that both sites had the same surface water mass present, Core $\mathrm{C}$ would have experienced higher average growth rates and hence lower fractionation, as found in this study.

The range of derived sea ice effective fractionation coefficients presented in this paper is consistent with the measurements of Melling and Moore (1995), where values of $1.5 \%$ to $2.7 \%$ were obtained. Equation 2 and the results in Tables 1a and $1 \mathrm{~b}$ can be used to inform studies calculating component proportions of water masses. In the past, such studies have generally picked a single number for the sea ice effective fractionation coefficient, for example Bausch et al. (1995) used 2.1\%o based on the mean value of Melling and Moore (1995), whereas Erwurzel et al. (2001), Bauch et al. (2012), and Newton et al. (2013) used $2.6 \%$, which is a value close to the expected equilibrium (very slow growth rate, as expected late in the sea ice growth season) value. 
"Surface water mass composition changes captured by cores of Arctic land-fast sea ice"

-revised manuscript submitted to Continental Shelf Research

\subsection{Hydrographic variations most likely explanation for more negative reconstructed $\delta^{18} \mathbf{O}_{\mathbf{w}}$}

The most likely explanation for the more negative reconstructed $\delta^{18} \mathrm{O}_{\mathrm{w}}$ values is the advection of a water mass with a large meteoric water component (precipitation and/or river water).

Such water would have low salinity as well as more negative $\delta^{18} \mathrm{O}$ signature, distinguishing it from low salinity water due to sea ice melt from the previous season, which would have a more positive $\delta^{18} \mathrm{O}$ signature. Unlike the sites with large rivers examined by Macdonald et al. (1999) and Eicken et al. (2005), the measurements reported in this paper were from sites and time of year where the local, relatively small rivers are not known to flow in winter.

Supporting this explanation, the B1 mooring data (Fig. 5) indicate that there were low salinity episodes throughout the growth season. Without CTD casts, we do not know the depth of the mixed layer and therefore we cannot infer that the water masses detected at B1 at depths of between $29.5 \mathrm{~m}$ and $34.6 \mathrm{~m}$ are the same as those at the surface. However, the mooring data qualitatively supports the hypothesis that lower salinity water masses were a persistent feature of the 2011/2012 sea ice growth season. Specifically, the mooring data (Fig. 5) show both episodic incursions of low-salinity water masses (lower by 2-3 psu) at the B1 site, as well as a slight, but significant freshening trend by about 0.5 ppt over the course of the ice season at both sites. As shown by Tamura and Ohshima (2011) and Iwamoto et al. (2014), the coastal polynyas in the region upstream of the mooring on average produce between a few to $>10 \mathrm{~m}$ of sea ice per year, which would suggest gradual salinization and not freshening of these waters. However, 2011/12 may have had anomalously low ice production based on reports of closed lead systems during much of the time period January through early April (Leavitt et al., 2013). Although unusual, anomalously low salinity events that season, 
"Surface water mass composition changes captured by cores of Arctic land-fast sea ice"

-revised manuscript submitted to Continental Shelf Research

especially in March 2012, were also measured by the JAMSTEC moorings located in Barrow Canyon (Motoyo Itoh, pers.comm., 2014). Possible sources for this low salinity water, include continued river or fresher lagoon discharge well into the winter (such as at Kuk Lagoon, where subsistence harvests indicated some degree of freshwater discharge in winter (Nelson, 1981)), or advection of Colville River or Mackenzie River water, or seasonal variations in isotopic composition advected through Bering Strait northwards along the coast that may have been preserved all the way up to Barrow.. However, it is beyond the scope of this paper and beyond the limitations of the available data set to definitively settle the issue of water origin.

In the Arctic, quantifying the relationship between low salinity waters and low $\delta^{18} \mathrm{O}_{\mathrm{w}}$ values is potentially problematic. Strain and Tan (1993) reported that when sea ice formation is occurring, the relationship between $\delta^{18} \mathrm{O}_{\mathrm{w}}$ and salinity will be linear in shape but the slope will evolve over time. This means that equations that relate $\delta^{18} \mathrm{O}_{\mathrm{w}}$ and salinity, such as those given by Cooper et al. (2005) and Yamamoto-Kawai et al. (2010), cannot be applied to our data because they sampled during shorter intervals, later in the season, and in different years (May-June 2002 for Cooper et al. (2005), and October 2002 for Yamamoto-Kawai et al. (2010)) compared to our cores (approximately 14 November 2011 to 3 April 2012 for Core B, and approximately 8 February to 6 April 2012 for Core C). Figure 1 of Cooper et al. (2005) shows the late spring-summer transition from a linear relationship between $\delta^{18} \mathrm{O}_{\mathrm{w}}$ and salinity (May-June 2002) to a lack of correlation between $\delta^{18} \mathrm{O}_{\mathrm{w}}$ and salinity in the summer melt period (July-August 2002). Our data point for both sea water $\delta^{18} \mathrm{O}_{\mathrm{w}}$ and sea water salinity was obtained at approximately the same time (Core B site in early April 2012) and has a slightly lower salinity and $\delta^{18} \mathrm{O}_{\mathrm{w}}$ values than the lowest limits of the May-June 2002 values shown in Figure 1 of Cooper et al. (2005). The data used by Cooper et al. (2005) are 
"Surface water mass composition changes captured by cores of Arctic land-fast sea ice"

-revised manuscript submitted to Continental Shelf Research

publicly available (http://www.eol.ucar.edu/projects/sbi/waterchemistry.shtml), and from analysis of that data we found that few of the data points were surface coastal waters (less than $100 \mathrm{~m}$ deep) that would be comparable with ours. Our measurement also has slightly lower $\delta^{18} \mathrm{O}_{\mathrm{w}}$ than the July-August 2002 values shown in Figure 1 of Cooper et al. (2005). This emphasizes how unusual these early spring measurements are compared to the published literature.

The predominant alongshore current direction seen for the B1 mooring data, which is near the Core $\mathrm{C}$ site, implies that lower $\delta^{18} \mathrm{O}_{\mathrm{w}}$ water could be following bathymetric contours (or, more formally, $f / H$ contours, where $f$ is the Coriolis parameter and $H$ is the depth) along the coast with Alaskan Coastal Current. As noted earlier, the data set available for 2011/2012 lacks information to allow determination of the source of the lower $\delta^{18} \mathrm{O}_{\mathrm{w}}$ water.

\subsection{Complicating factors when comparing core sites}

The deeper snow cover at the Core B site compared to the Core C site is likely to be a result of the sea ice at the Core B site forming and becoming land-fast earlier than at the Core $\mathrm{C}$ site which allowed more snow to accumulate. The thicker sea ice at the Core B site compared to the Core $\mathrm{C}$ site is also a result of the earlier freeze-up dates for the Core B site. For the period of temporal overlap between the two cores, i.e., after 8-10 February 2012, when sea ice had formed at site $\mathrm{C}$, variations in reconstructed $\delta^{18} \mathrm{O}_{\mathrm{w}}$ are roughly in phase but exhibit different magnitudes at the two core sites (Fig. 4). Summer measurements at Barrow confirm that there is considerable fine structure in the coastal waters (Johnson et al., manuscript in preparation) and in the larger vicinity (Okkonen et al., 2009). Hence, differences between the two sites 
"Surface water mass composition changes captured by cores of Arctic land-fast sea ice" -revised manuscript submitted to Continental Shelf Research

may also reflect persistent differences in surface water composition. Differences in lateral mixing of parent water masses for water transported to the two locations may also contribute to the observed signals

Our method does not take into account variations in current velocities, which may be different at the two sites. Current velocities will affect the boundary layer thickness, and fractionation coefficients depend on boundary layer thickness, so this would be a suitable topic for future fieldwork to investigate.

\section{Conclusions}

In this paper, we have demonstrated that changes in present day Arctic Ocean surface water masses (as indicated by oxygen isotope composition) due to episodic advection of meteoric water can be detected in land-fast sea ice cores using the method of Smith et al. (2015). Meteoric water, having both lower salinity and lower oxygen isotopic composition, was present during the winter sea ice growth season. Such advection of meteoric water during winter is surprising, as no surface meltwater and no local river discharge were known to be present at this time of year in that area. The method works well in this case because the uncertainty of the reconstructed ocean $\delta^{18} \mathrm{O}$ values $( \pm 0.2 \%$ ) is much less than the changes in the reconstructed ocean $\delta^{18} \mathrm{O}$ values (approximately 1.8 to $1.9 \%$ ). Methods/strategies that could be used to optimize the results further include having higher precision available from instruments used to measure sea ice $\delta^{18} \mathrm{O}$, having a longer time series of validation data available for sea ice growth rates, having a long time series of snow thicknesses available, 
"Surface water mass composition changes captured by cores of Arctic land-fast sea ice"

-revised manuscript submitted to Continental Shelf Research

and having more detailed information on when the sea ice formed and became land-fast.As for the Antarctic case (Smith et al., 2015), the biggest hurdle for optimizing results is the requirement to parameterise or measure the ocean heat flux, which is a barrier to the method being an entirely retrospective method (i.e., one requiring only observational data from the end of the sea ice growth season on sea ice $\delta^{18} \mathrm{O}$, snow depth, and ice formation dates). However, we have shown that the standard ocean-to-ice heat flux assumption for the Arctic ( $2 \mathrm{~W} \mathrm{~m}^{-2}$; Maykut and Untersteiner, 1971) is a reasonable one. Further measurements and parameterisations of ocean heat flux in the Arctic would be useful for future applications of the model in order to optimize the results. In addition, a much more detailed survey of isotopic composition of water masses in the region than what is currently available (Cooper et al., 2005) is required that captures the local hydrography so that connections between salinity and oxygen isotope values can be further explored. Such connections are important in fields such as high latitude paleoclimate studies that use foraminifera, where challenges caused by the influence of sea ice production rates on the salinity and oxygen isotope relationships have been noted (Hillaire-Marcel, 2011), particularly the deviation from Arctic river signatures caused by sea ice (Hillaire-Marcel, 2011 citing Frew et al., 2000).

Winter detection of meteoric water presence in Arctic fast ice regions is important for climate studies in a rapidly changing Arctic, yet we are lacking year-round studies of water mass changes in the regions north of Bering Strait and in the southern Chukchi and Beaufort Seas where potential impacts are greatest. Making ocean observations during winter is challenging, which has resulted in sparse knowledge of winter Arctic coastal water mass changes in this region. Moorings cannot capture near-surface water mass changes because they are normally deployed at depth and sea ice interferes with the operation of their component instruments. 
"Surface water mass composition changes captured by cores of Arctic land-fast sea ice"

-revised manuscript submitted to Continental Shelf Research

This method provides a way of filling this gap by using sea ice as an archive of winter surface ocean changes.

The method used here built on and improved that of Pfirman et al. (2004), used data from the end of the sea ice growth season on sea ice $\delta^{18} \mathrm{O}$, snow depth, and ice formation dates, along with a thermodynamic sea ice model (Bitz and Lipscomb, 1999) driven with reanalysis data (Rienecker et al., 2011), and equations linking sea ice growth rates with effective fractionation coefficients (Eicken, 1998, as modified by Smith et al., 2012, and Toyota et al., 2013). Land-fast sea ice effective fractionation coefficients were derived, with a range of $+1.82 \%$ to $+2.52 \%$. Those derived effective fractionation coefficients will be useful for future water mass component proportion calculations. In particular, the equations given can be used to inform choices made when engaging in end member determination for working out the component proportions of water masses.

\section{Acknowledgements}

Thanks to Matt Druckenmiller, Chris Polashenski, Stefan Hendricks, Priska Hunkeler, Greg Deemer and the Umiaq/CPS logistics and field team (GlennRoy Nashaknik, Justin Gatten, Tony Kaleak, Michael Qunniq Donovan, Brower Frantz, Eric Burnett, Josh Bacon, Faustine Bernadac, and Cody Johnson, and Karl Newyear) for fieldwork support and assistance, Mette Kaufman and Dianne Clark for lab support, Kay Ohshima and Daisuke Simizu for their involvements in ocean mooring data collection, Matt Parry for statistical and data analysis discussions and suggestions, and Jono Everts for his efforts with Matlab graphics. We are 
"Surface water mass composition changes captured by cores of Arctic land-fast sea ice" -revised manuscript submitted to Continental Shelf Research

grateful to Robert Newton and an anonymous reviewer for constructive suggestions that helped improve the paper. IJS wishes to thank Mike Williams from NIWA, Paul Woodgate and Chris Gilbert from Antarctica New Zealand, and Pat Langhorne from the University of Otago for equipment loaned to her that assisted her involvement in the project. The fieldwork for this project was part of SIZONet Phase II, NSF grant number 0856967. The involvement of IJS in this project was funded by University of Otago Research Grants 108646 (2012) and 109432 (2013) and her collaborative travel through an Office of Naval Support Global Visitor Support Program Grant N62909_13_1_V084 (2013).

\section{References}

Bauch, D., Hölemann, J.A., Dmitrenko, I.A., Janout, M.A., Nikuline, A., Kirillow, S.A., Krumpen, T., Kassens, H., Timokhov, L. 2012. Impact of Siberian coastal polynyas on shelf-derived Arctic Ocean halocline waters. Journal of Geophysical Research Oceans, 117: C00G12, doi: 10.1029/2011JC007282.

Bauch, D., Schlosser, P., Fairbanks, R.G. 1995. Freshwater balance and the sources of deep and bottom waters in the Arctic Ocean inferred from the distribution of $\mathrm{H}_{2}{ }^{18} \mathrm{O}$. Progress in Oceanography, 35:53-80.

Bitz, C.M. and Lipscomb, W.H. 1999. An energy-conserving thermodynamic model of sea ice. Journal of Geophysical Research 104(C7):15669-15677. 
"Surface water mass composition changes captured by cores of Arctic land-fast sea ice"

-revised manuscript submitted to Continental Shelf Research

Cavalieri, D.J., Parkinson, C.L. 2012. Arctic sea ice variability and trends, 1979-2010. The Cryosphere, 6, 881-889, doi:10.5194/tc-6-881-2012.

Comiso, J.C. 2012. Large Decadal Decline of the Arctic Multiyear Ice Cover. Journal of Climate, 25(4): 1176-1193 , doi:10.1175/JCLI-D-11-00113.1.

Cooper, L.W, Benner, R., McClelland, J.W., Peterson, B.J., Holmes, R.M., Raymond, P.A., Hansell, D.A., Grebmeier, J.M., Codispoti, L.A. 2005. Linkages among runoff, dissolved organic carbon, and the stable oxygen isotope composition of seawater and other water mass indicators in the Arctic Ocean. Journal of Geophysical Research, 110: G02013, doi: 10.1029/2005JG000031.

Druckenmiller, M.L., Eicken, H., Pringle, D.J., Williams, C.C., Johnson, M.A., 2009. Towards an integrated coastal sea-ice observatory: System components and a case study at Barrow, Alaska. Cold Reg. Sci. Tech. 56, 61-72.

Eicken, H., R. Gradinger, T. Heinrichs, M. Johnson, A. Lovecraft, and M. Kaufman. (2009, updated 2012). Automated ice mass balance site (SIZONET). UCAR/NCAR -- CISL -- ACADIS. http://dx.doi.org/10.5065/D6MW2F2H

Eicken, H., 1998. Deriving modes and rates of ice growth in the Weddell Sea from microstructural, salinity, and stable-isotope data. Antarctic Research Series. 74, 89122. 
"Surface water mass composition changes captured by cores of Arctic land-fast sea ice"

-revised manuscript submitted to Continental Shelf Research

Eicken, H., Dmitrenko, T.I., Tyshko, K., Darovskikh, A., Dierking, W., Blahak, U., Groves, J., Kassens, H. 2005. Zonation of the Laptev Sea landfast ice cover and its importance in a frozen estuary. Global and Planetary Change, 48: 55-83, doi:10.1016/j.gloplacha.2004.12.005.

Eicken, H., R. Gradinger, T. Heinrichs, M. Johnson, A. Lovecraft, Fukamachi, Y., K. I. Ohshima, D. Simizu, T. Takatsuka, K. Iwamoto, and M. Kaufman. (May 17, 2011, Updated Sept 4, 2014). Mooring Temperature/Conductivity \& Temperature/Pressure data (SIZONET). UCAR/NCAR - CISL - ACADIS. http://dx.doi.org/10.5065/D6BG2KW9.

Ekwurzel, B., Schlosser, P., Mortlock, R.A., Fairbanks, R.G., Swift, J.H. 2001. River runoff, sea ice meltwater, and Pacific water distribution and mean residence times in the Arctic Ocean. Journal of Geophysical Research, 106(C5): 9075-9092.

Frew, R.D., Dennis, P.F., Heywood, K.J., Meredith, M.P. and Boswell, S.M. 2000. The oxygen isotope composition of water masses in the northern North Atlantic. Deep-Sea Res. 47 2265-2286

Fukamachi, Y., K. Ohshima, D. Simizu, T. Takatsuka, K. Iwamoto, A. Mahoney, J. Jones, H. Eicken. (May 16, 2011, Updated Oct. 22, 2014). Mooring ADCP data (SIZONET). UCAR/NCAR - CISL - ACADIS. http://dx.doi.org/10.5065/D6G44N6Q. 
"Surface water mass composition changes captured by cores of Arctic land-fast sea ice"

-revised manuscript submitted to Continental Shelf Research

Hillaire-Marcel, C. 2011. Foraminifera isotopic records... with special attention to high northern latitudes and the impact of sea-ice distillation processes, IOP Conf. Series: Earth and Environmental Science 14 (2011) 012009, doi:10.1088/17551315/14/1/012009.

Hutchings, J. K., Rigor, I. G., 2012. Role of ice dynamics in anomalous ice conditions in the Beaufort Sea during 2006 and 2007, J. Geophys. Res., 117, C00E04, doi:10.1029/2011JC007182.

Iwamoto, K., Ohshima, K.I., and Tamura, T. 2014. Improved mapping of sea ice production in the Arctic Ocean using AMSR-E thin ice thickness algorithm. Journal of Geophysical Research - Oceans, 119: 3574-3594, doi: 10.1002/2013JC009749.

Jones, J., Eicken, H., Mahoney, A., Rohith MV, Kambhamettu, C., Fukamachi, Y., Ohshima, K. (to be submitted) Landfast Sea Ice Breakouts Near Barrow, Alaska: Two Case Studies on the Formation and Failure of Stabilizing Features. to be submitted to Cont. Shelf Res.

Laxon, S.W., Giles, K.A., Ridout, A.L., Wingham, D.J., Willatt, R., Cullen, R., Kwok, R., Schweiger, A., Zhang, J., Haas, C., Hendricks, S., Krishfield, R., Kurtz, N., Farrell, S., Davidson, M. 2013. CryoSat-2 estimates of Arctic sea ice thickness and volume. Geophysical Research Letters, 40(4): 732-737, doi: 10.1002/grl.50193. 
"Surface water mass composition changes captured by cores of Arctic land-fast sea ice"

-revised manuscript submitted to Continental Shelf Research

Leavitt, J., Apangalook, L., P. Apangalook, S. John, W. Weyapuk, Jr., and other observers. 2013. Local Observations from the Seasonal Ice Zone Observing Network (SIZONet). Edited by H. Eicken and M. Kaufman. Boulder, Colorado USA: National Snow and Ice Data Center. http://dx.doi.org/10.7265/N5TB14VT.

Macdonald, R.W., Carmack, E.C., Paton, D.W. 1999. Using the $\delta^{18}$ O composition in landfast ice as a record of arctic estuarine processes. Marine Chemistry 65:3-24.

Mahoney, A., Eicken, H., Shapiro, L.H., 2007. How fast is landfast sea ice? A study of attachment and detachment of nearshore ice at Barrow, Alaska. Cold Reg. Sci. Tech. 47, 233-255.

Martin, S., R. Drucker, R. Kwok, and B. Holt. 2005. Improvements in the estimates of ice thickness and production in the Chukchi Sea polynyas derived from AMSR-E. Geophysical Research Letters, 32(5), 1-4.

Maykut, G.A., Untersteiner, N. 1971. Some results from a time-dependent thermodynamic model of sea ice. Journal of Geophysical Research, 76(6): 1550-1575.

Melling, H., Moore, R.M. 1995. Modification of halocline source waters during freezing on the Beaufort Sea shelf: evidence from oxygen isotopes and dissolved nutrients. Continental Shelf Research, 15(1): 89-113. 
"Surface water mass composition changes captured by cores of Arctic land-fast sea ice"

-revised manuscript submitted to Continental Shelf Research

Nelson, R.K. 1981. Harvest of the sea: coastal subsistence in modern Wainwright. North Slope Borough. 126 pp.

Newton, R., Schlosser, P., Mortlock, R., Swift, J., MacDonald, R. 2013. Canadian Basin freshwater sources and changes: results from the 2005 Arctic Ocean Section. Journal of Geophysical Research Oceans, 118:2133-2154, doi: 10.1002/jgrc.20101.

Okkonen, S.R., Ashjian, C.J., Campbell, R.G., Maslowski, W., Clement-Kinney, J.L., Potter, R. 2009. Intrusion of warm Bering/Chukchi waters onto the shelf in the western Beaufort Sea. Journal of Geophysical Research Oceans, 114(C00A11), doi: 10.1029/2008JC004870.

Perovich, D.K., Jones, K.F., Light, B., Eicken, H., Markus, T., Stroeve, J., Lindsay, R., 2011. Solar partitioning in a changing Arctic sea-ice cover. Ann. Glaciol. 52, 192-196.

Pfirman, S., Haxby, W., Eicken, H., Jeffries, M., Bauch D., 2004. Drifting Arctic sea ice archives changes in ocean surface conditions, Geophysical Research Letters. 31, L19401, doi:10.1029/2004GL020666.

Pickart, R. S., M. A. Spall, G. W. K. Moore, T. J. Weingartner, R. A. Woodgate, K. Aagaard, and K. Shimada. 2011. Upwelling in the Alaskan Beaufort Sea: Atmospheric forcing and local versus non-local response, Progress in Oceanography. 88(1-4), 78-100. 
"Surface water mass composition changes captured by cores of Arctic land-fast sea ice"

-revised manuscript submitted to Continental Shelf Research

Pistone, K., Eisenman, I., Ramanathan, V., 2014. Observational determination of albedo decrease caused by vanishing Arctic sea ice. Proc. Natl. Acad. Sci. USA, 111, 33223326.

Rienecker, M. M., Suarez, M. J., Gelaro, R., Todling, R., Bacmeister, J., Liu, E., Bosilovich, M. G., Schubert, S. D., Takacs, L., Kim, G.-K., Bloom, S., Chen, J., Collins, D., Conaty, A., da Silva, A., Gu, W., Joiner, J., Koster, R. D., Lucchesi, R., Molod, A., Owens, T., Pawson, S., Pegion, P., Redder, C. R., Reichle, R., Robertson, F. R., Ruddick, A. G., Sienkiewicz, M., and Woollen, J. 2011. MERRA: NASA’s ModernEra Retrospective Analysis for Research and Applications. J. Climate, 24(14), 36243648.

Smith, I.J., Gough, A.J., Langhorne, P.J., Mahoney, A.R., Leonard, G.H., Van Hale, R., Jendersie, S., Haskell, T.G. 2015. First year land-fast Antarctic sea ice as an archive of ice shelf meltwater fluxes. Cold Regions Science and Technology, 113:63-70, doi: 10.1016/j.coldregions.2015.01.007.

Smith, I. J., Langhorne, P. J., Frew, R.D., Vennell, R., and Haskell, T. G, 2012. Sea ice growth rates near ice shelves, Cold Regions Science and Technology, 83-84:57-70, doi: 10.1016/j.coldregions.2012.06.005.

Strain, P.M., Tan, F.C. 1993. Seasonal evolution of oxygen isotope-salinity relationships in high-latitude surface waters. Journal of Geophysical Research, 98(C8): 14,58914,598 . 
"Surface water mass composition changes captured by cores of Arctic land-fast sea ice"

-revised manuscript submitted to Continental Shelf Research

Tamura, T., and K. I. Ohshima. 2011. Mapping of sea ice production in the Arctic coastal polynyas, Journal of Geophysical Research-Oceans, 116 (C07030), doi:10.1029/2010JC006586.

Toyota, T., Smith, I.J., Gough, A.J., Langhorne, P.J., Leonard, G.H., Van Hale, R.J., Mahoney, A.R.Haskell, T.G. 2013. Oxygen isotope fractionation during the freezing of sea water, Journal of Glaciology, 59(216): 697-710, doi:10.3189/2013JoG12J163.

Vancoppenolle, M., Bitz, C.M., Fichefet, T. 2007. Summer landfast sea ice desalination at Point Barrow, Alaska: Modeling and observations. Journal of Geophysical Research Oceans, 112(C04022), doi: 10.1029/2006JC003493.

Weingartner, T., Aagaard, K., Woodgate, R., Danielson, S., Sasaki, Y., Cavalieri, D. 2005. Circulation on the north central Chukchi Sea shelf. Deep Sea Research II - Topical Studies in Oceanography, 52: 3150-3174, doi:10.1016/j.dsr2.2005.10.015.

Weingartner, T. J., D. J. Cavalieri, K. Aagaard, and Y. Sasaki. 1998. Circulation, dense water formation, and outflow on the northeast Chukchi shelf, Journal of Geophysical Research-Oceans, 103(C4), 7647-7661.

Winsor, P., and G. Björk. 2000. Polynya activity in the Arctic Ocean from 1958 to 1997. Journal of Geophysical Research-Oceans, 105(C4), 8789-8803. 
"Surface water mass composition changes captured by cores of Arctic land-fast sea ice" -revised manuscript submitted to Continental Shelf Research

Woodgate, R.A., Weingartner, T., Lindsay, R., 2010. The 2007 Bering Strait oceanic heat flux and anomalous Arctic sea-ice retreat. Geophysical Research Letters 37, L01602, doi:10.1029/2009GL041621.

Yamamoto-Kawai, M., Carmack, E.C., McLaughlin, F.A., Falkner, K.K. 2010. Oxygen isotope ratio, barium and salinity in waters around the North American coast from the Pacific to the Atlantic: Implications for freshwater sources to the Arctic throughflow. Journal of Marine Research, 68(1): 97-117. 
-revised manuscript submitted to Continental Shelf Research

Fig. 1: Map of locations near Barrow, Alaska showing the UAF mass balance station (MBS) and two year-round oceanographic moorings (B1 and B2), as well the locations where cores $\mathrm{B}$ and $\mathrm{C}$ were extracted. The dashed red circle indicates the approximate range of the coastal sea ice radar while green and blue contours indicate the bathymetry at $5 \mathrm{~m}$ and $20 \mathrm{~m}$ intervals, respectively. The background image is a color-enhanced MODIS image from 8 April 2012 showing the flaw lead at the boundary of the land-fast sea ice. The insert shows the wider North Slope region of Alaska and its major rivers.

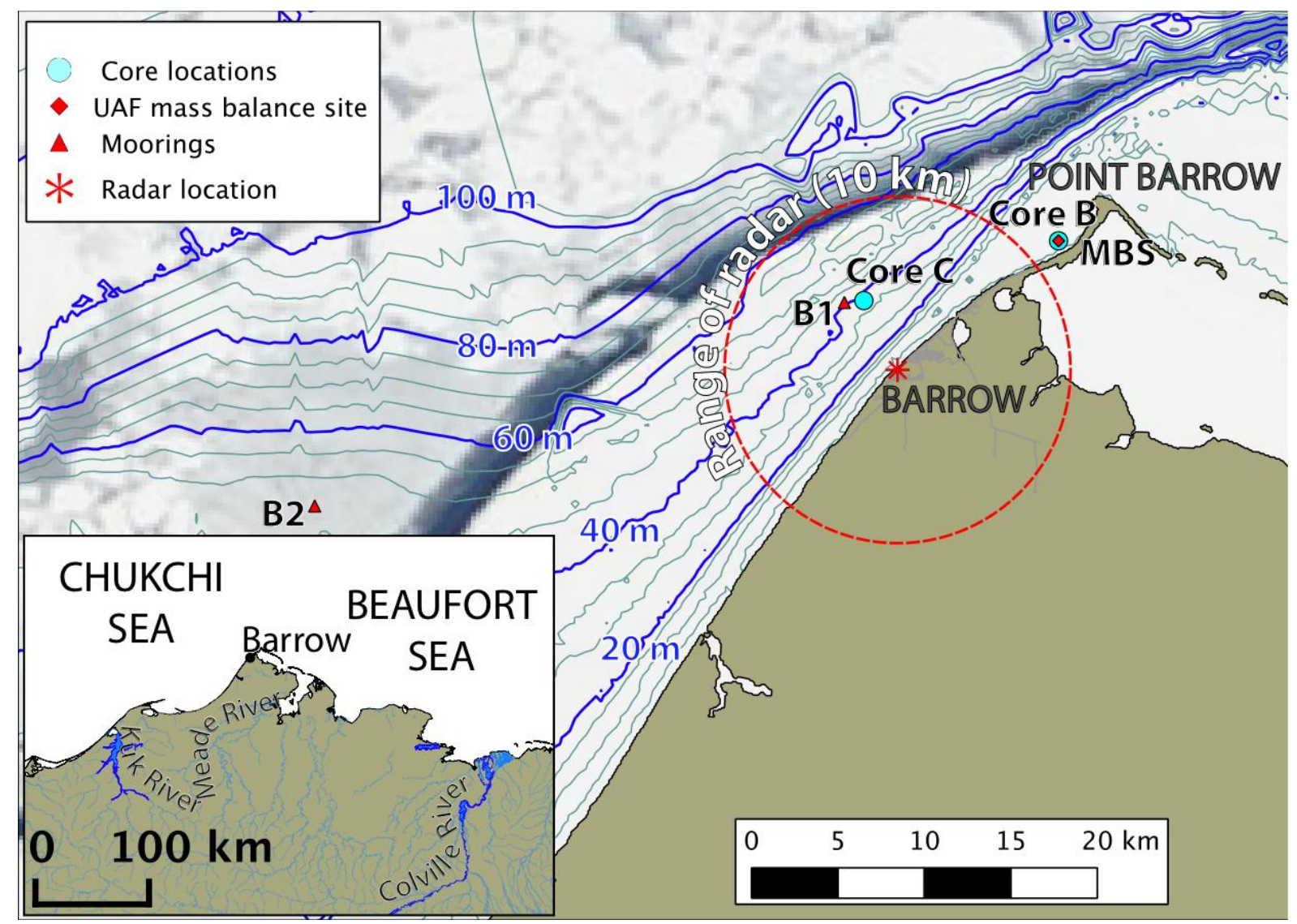


-revised manuscript submitted to Continental Shelf Research

Fig. 2: Growth rate graphs for 2012. The output of the Bitz and Lipscomb (1999) model runs are shown as circles, with each circle representing different combinations of ice formation date and snow accumulation scaling. Dashed line indicates the high growth rate regime with fractionation coefficients derived according to Toyota et al. (2013) (above the line) and the low growth rate regime with effective fractionation coefficients obtained according to Smith et al. (2012) (below the line).

(a) Core B: for start dates of ice formation of 14, 15 and 16 November 2011, and with snow depths obtained by scaling the reported MERRA precipitation field to reproduce $80 \%, 90 \%$, $100 \%, 110 \%$, and $120 \%$ of the measured total from 2 April $2012(19 \mathrm{~cm})$. Measured growth rates $(n=6)$ are shown as a red line with uncertainties as pink shading.

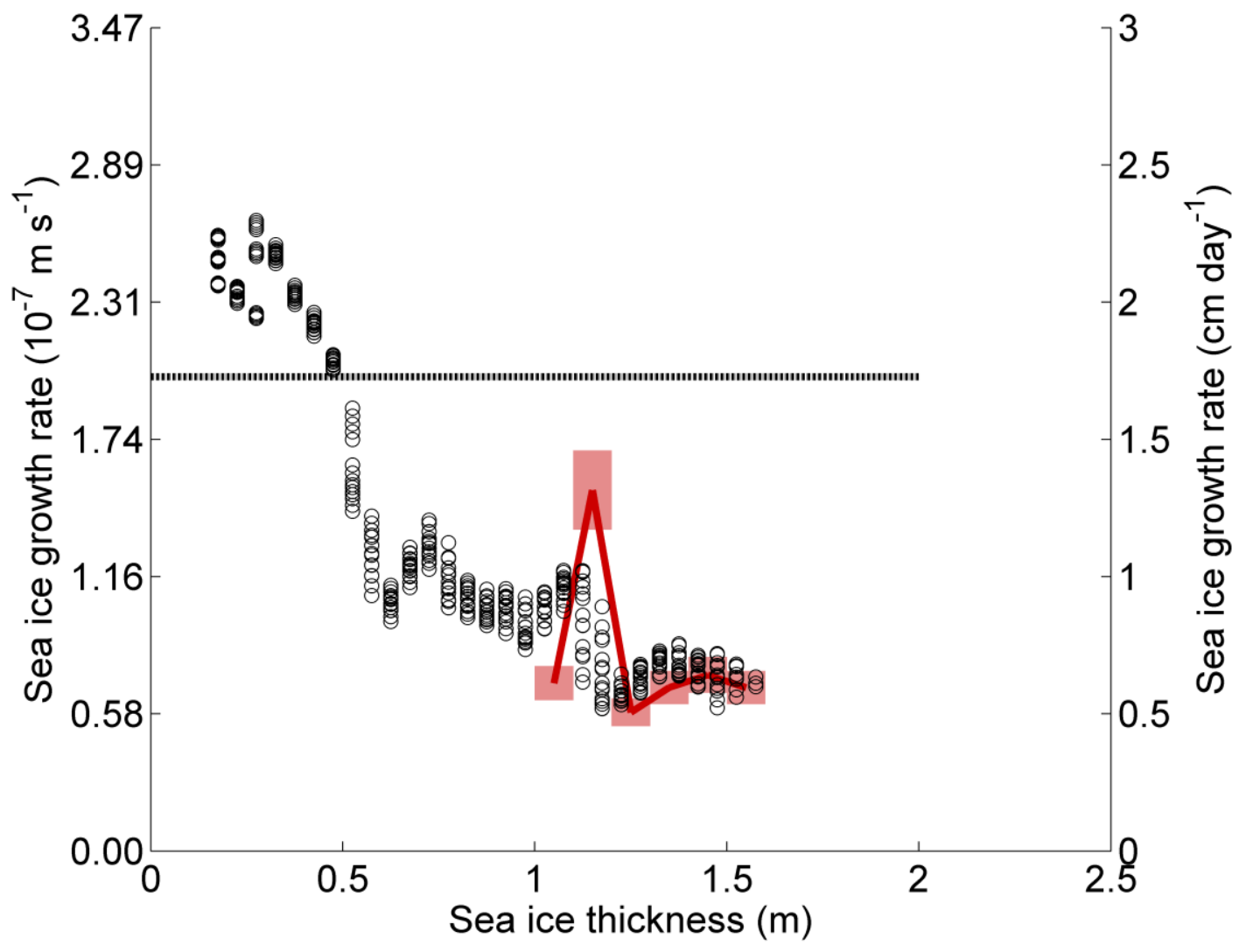

(b) Core C: for start date of ice formation of 8, 9, and 10 February 2012, and with snow depths obtained by scaling the reported MERRA precipitation field to reproduce $80 \%, 90 \%$, 
"Surface water mass composition changes captured by cores of Arctic land-fast sea ice" -revised manuscript submitted to Continental Shelf Research

$100 \%, 110 \%$, and $120 \%$ of the measured total from 6 April $2012(3.5 \mathrm{~cm})$. Measured growth rates were not available for this site.

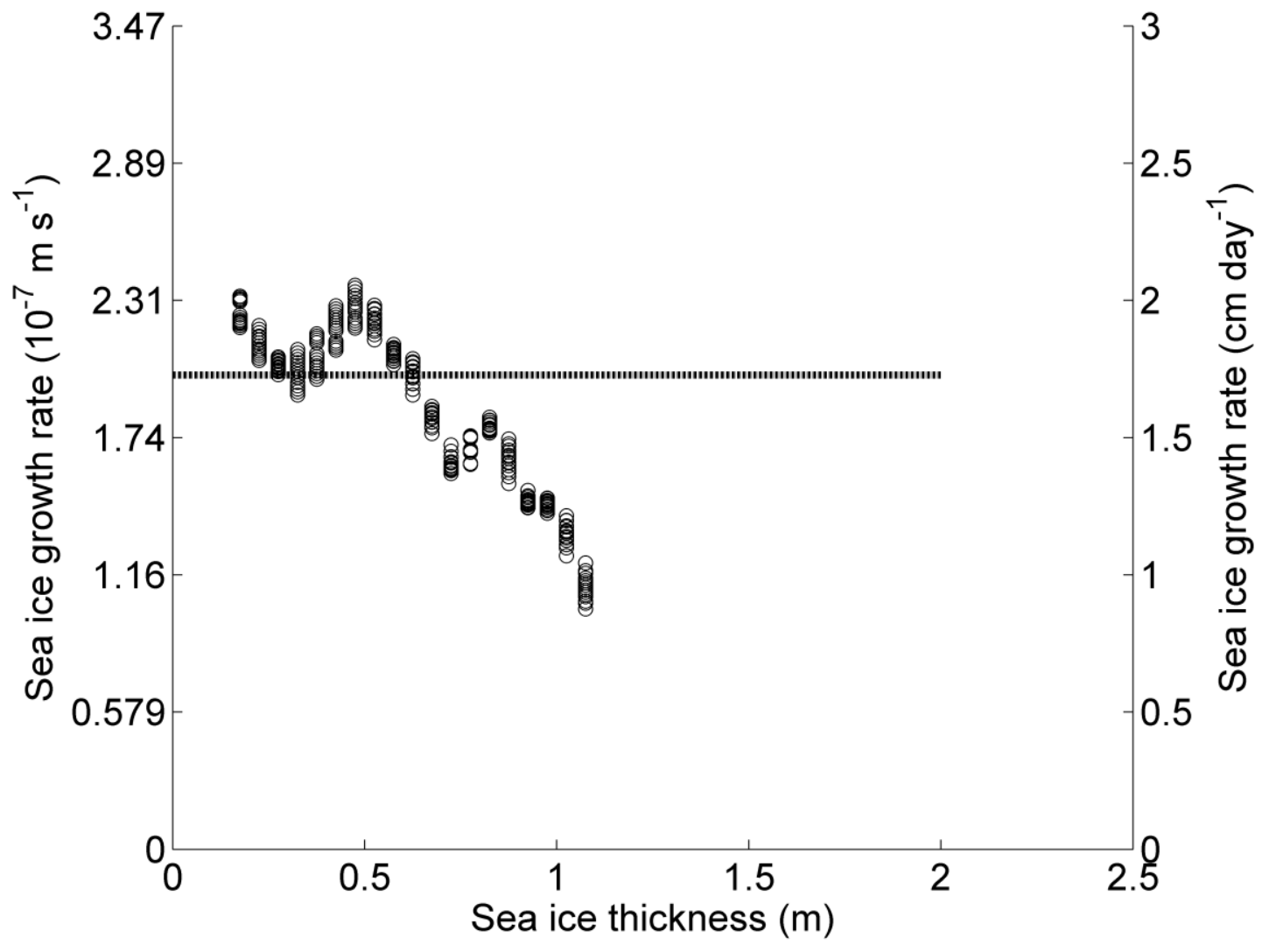


-revised manuscript submitted to Continental Shelf Research

Figure 3a: Salinity measurement results for Core B (blue: left hand vertical scale) and Core C (red: right hand vertical scale). Note that both cores were taken within a few days of each other (Core B: 3 April 2012; Core C: 6 April 2012), but that the sea ice at the Core C site started growing after that at the Core B site, and Core C is therefore shorter than Core B.

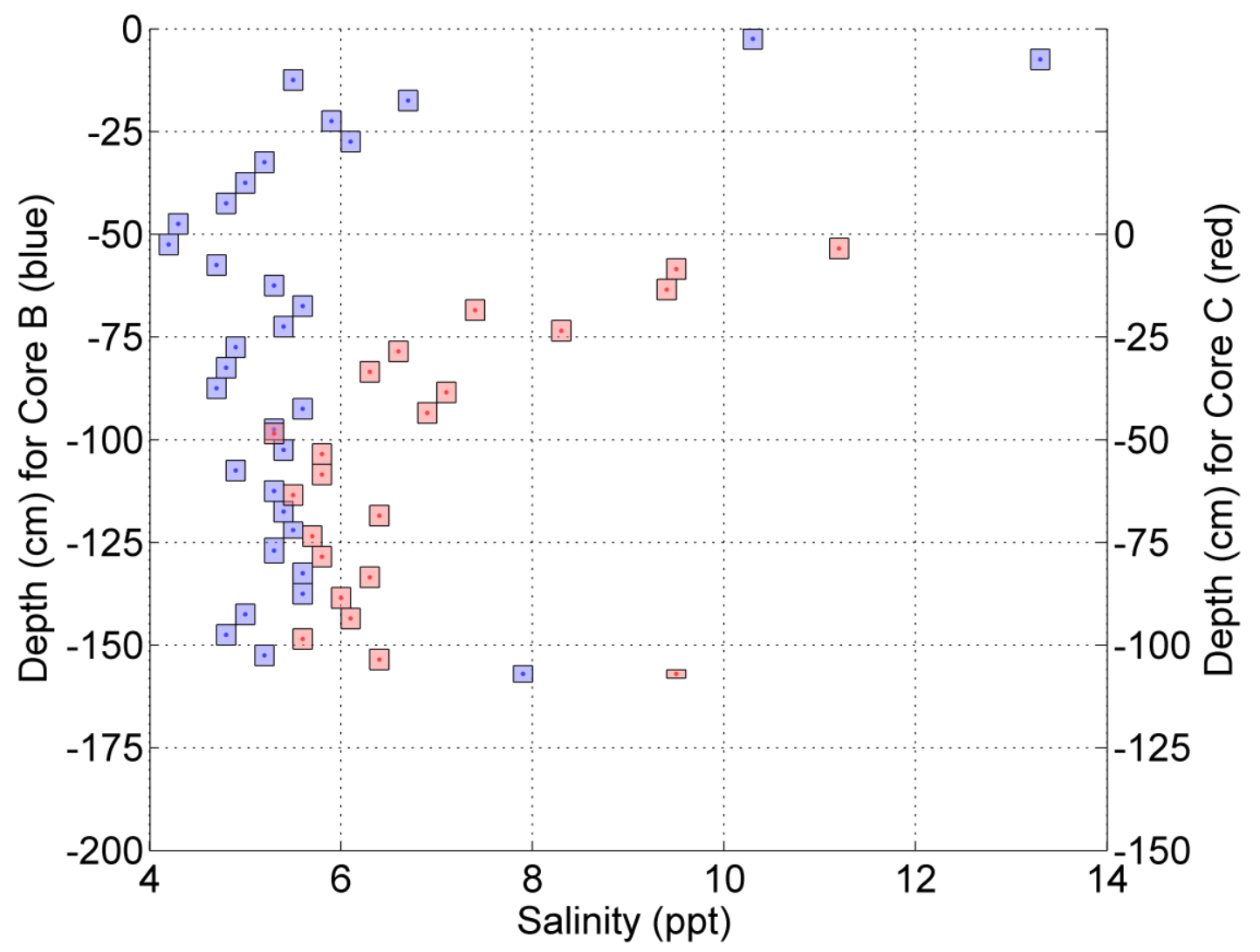


"Surface water mass composition changes captured by cores of Arctic land-fast sea ice"

-revised manuscript submitted to Continental Shelf Research

Figure 3b: Oxygen isotope results for Core B (blue: left hand vertical scale) and Core C (red: right hand vertical scale). Note that both cores were taken within a few days of each other (Core B: 3 April 2012; Core C: 6 April 2012), but that the sea ice at the Core C site started growing after that at the Core $\mathrm{B}$ site, and Core $\mathrm{C}$ is therefore shorter than Core $\mathrm{B}$.

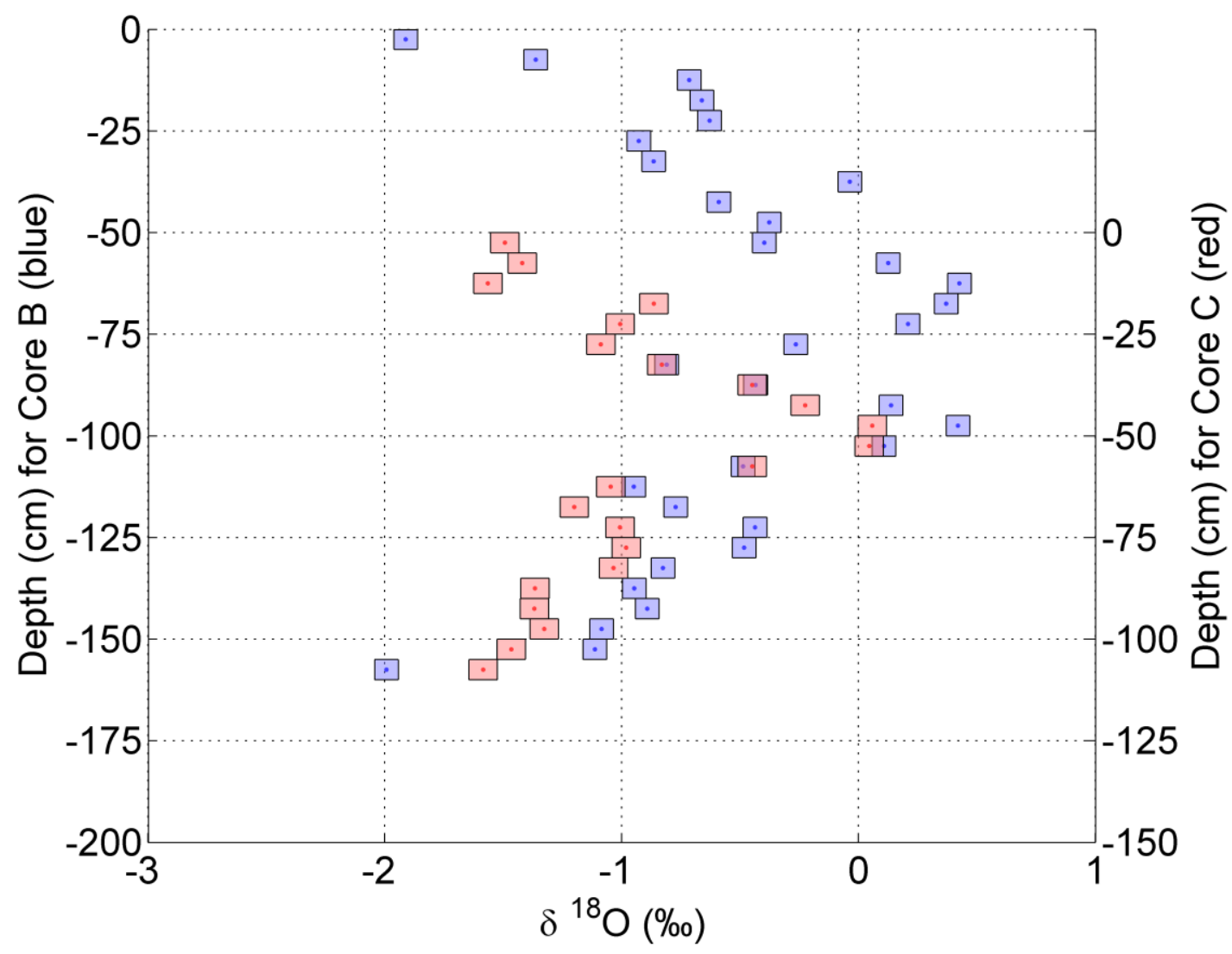


"Surface water mass composition changes captured by cores of Arctic land-fast sea ice" -revised manuscript submitted to Continental Shelf Research

Figure 4: Measured (circles) and reconstructed (boxes) sea water oxygen isotope results for Core B (black circle and blue boxes) and Core C (grey circle and red boxes).

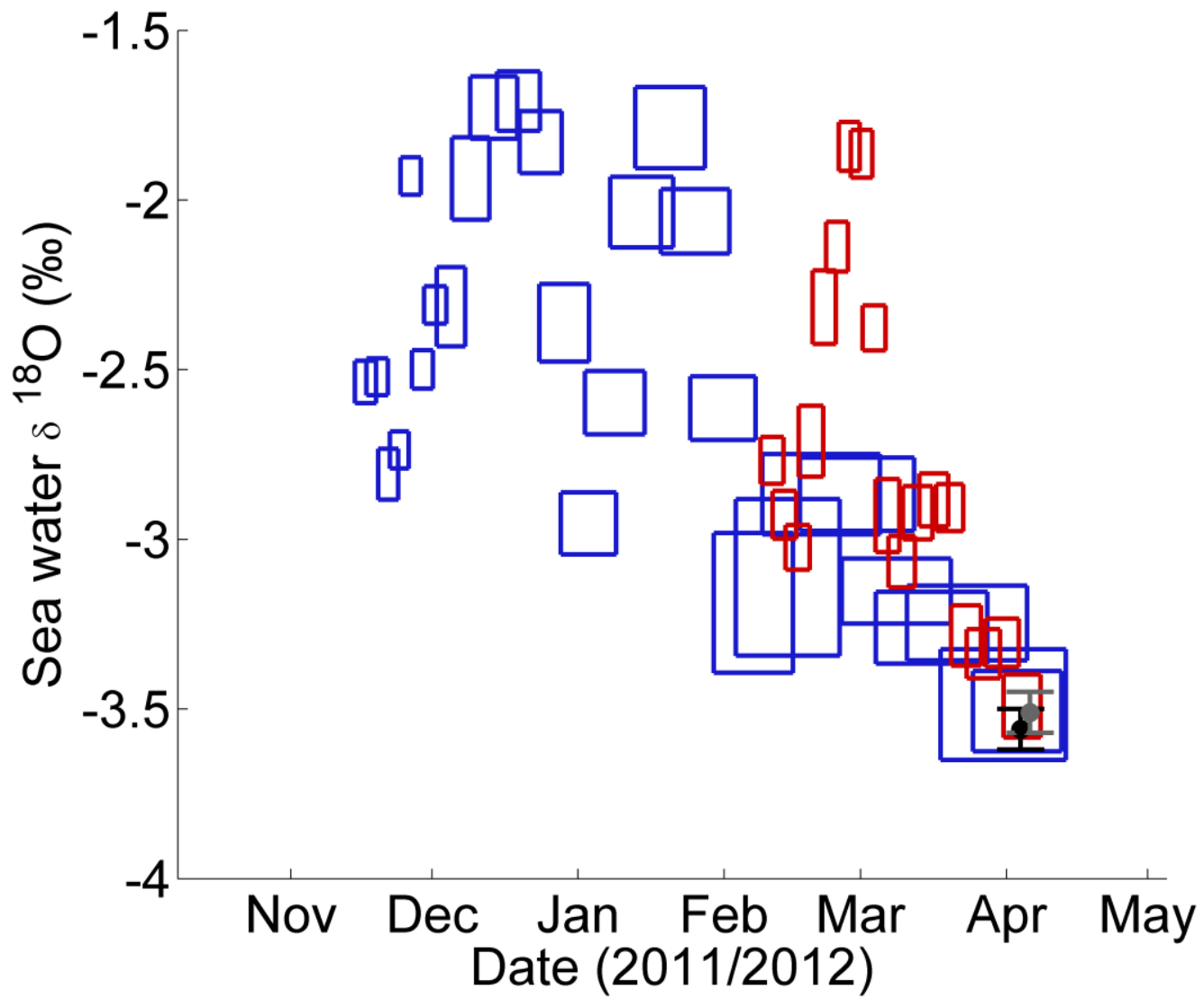


"Surface water mass composition changes captured by cores of Arctic land-fast sea ice" -revised manuscript submitted to Continental Shelf Research

Figure 5: Salinity data from mooring B1. Red is "raw" (14 November 2011 to 30 April 2012), and black is 5 day running mean.

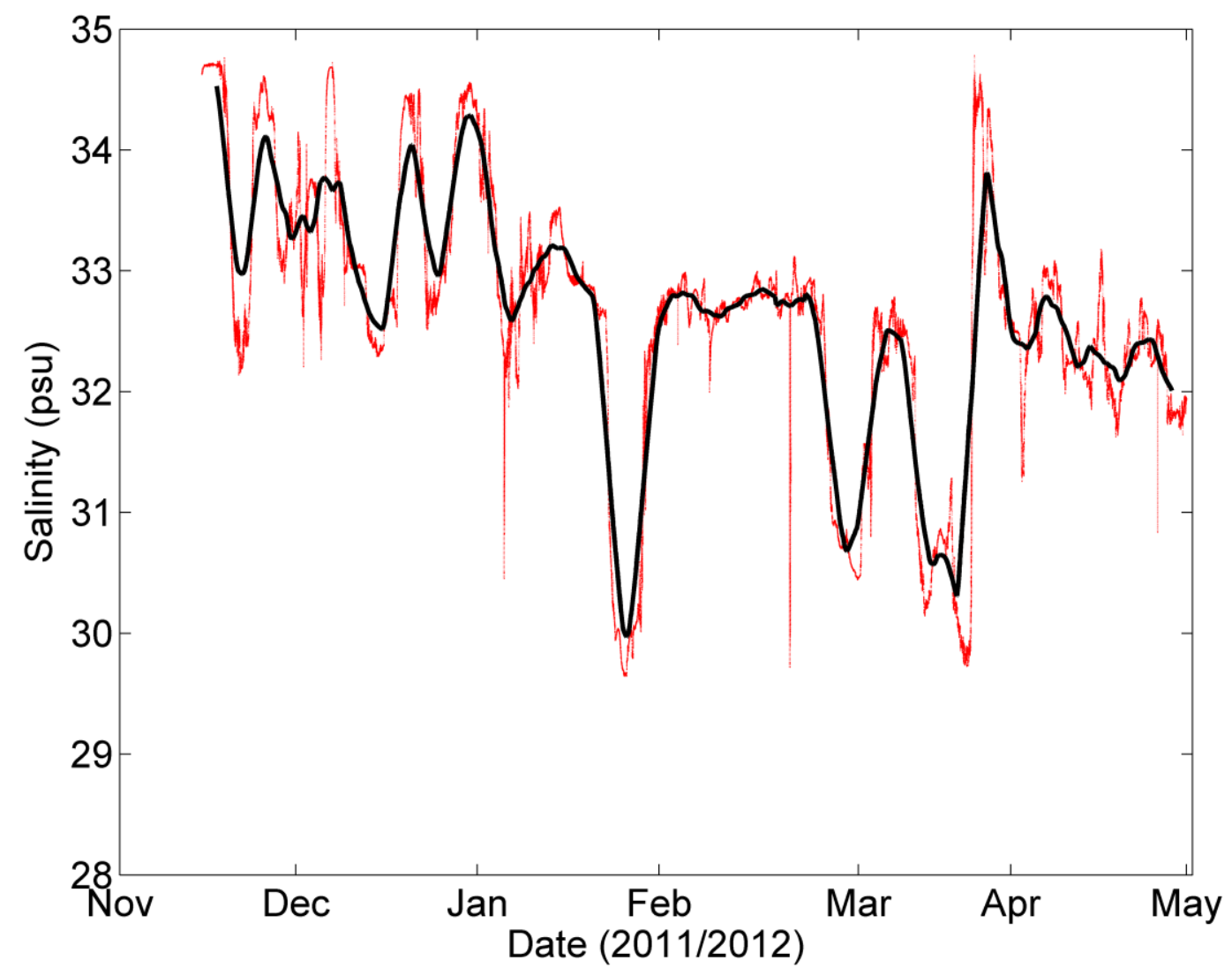


"Surface water mass composition changes captured by cores of Arctic land-fast sea ice"

-revised manuscript submitted to Continental Shelf Research

Figure 6: Current roses for moorings B1 (nearshore: water depth $41.5 \mathrm{~m}$, nominal ADCP depth $34.2 \mathrm{~m}$ ) and B2 (offshore: water depth $51.6 \mathrm{~m}$, nominal ADCP depth $44.3 \mathrm{~m}$ ) from November 2011 to May 2012. Arrows indicate the mean current speed in each direction range over this period. Red wedges indicate the frequency of currents in each direction range. Each current rose is centred at the location of the corresponding mooring relative to the coastline.

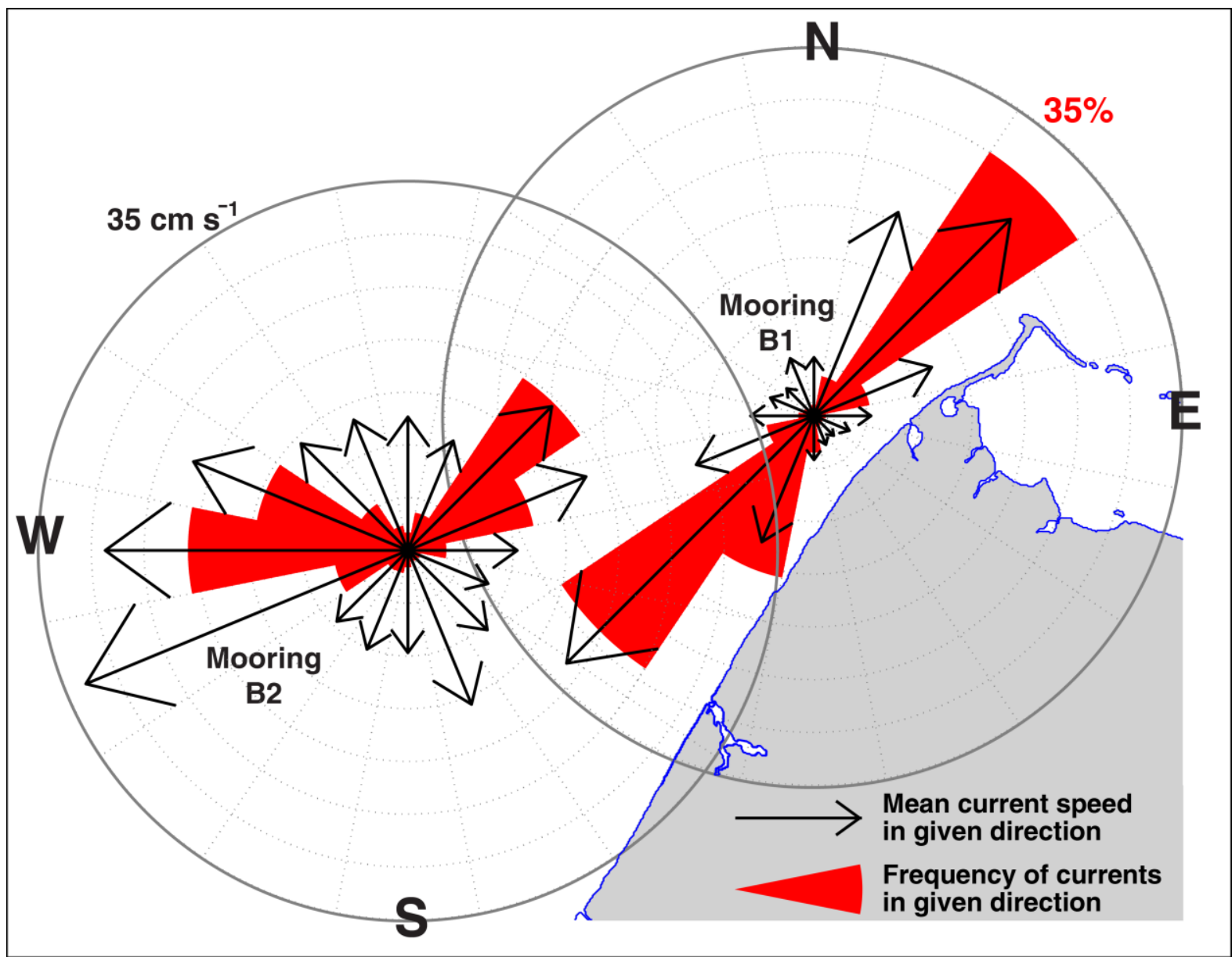


"Surface water mass composition changes captured by cores of Arctic land-fast sea ice"

-revised manuscript submitted to Continental Shelf Research

Figure 7: Timeseries from November 2011 to May 2012 of current speed and direction measured at a) mooring B1 and b) mooring B2.
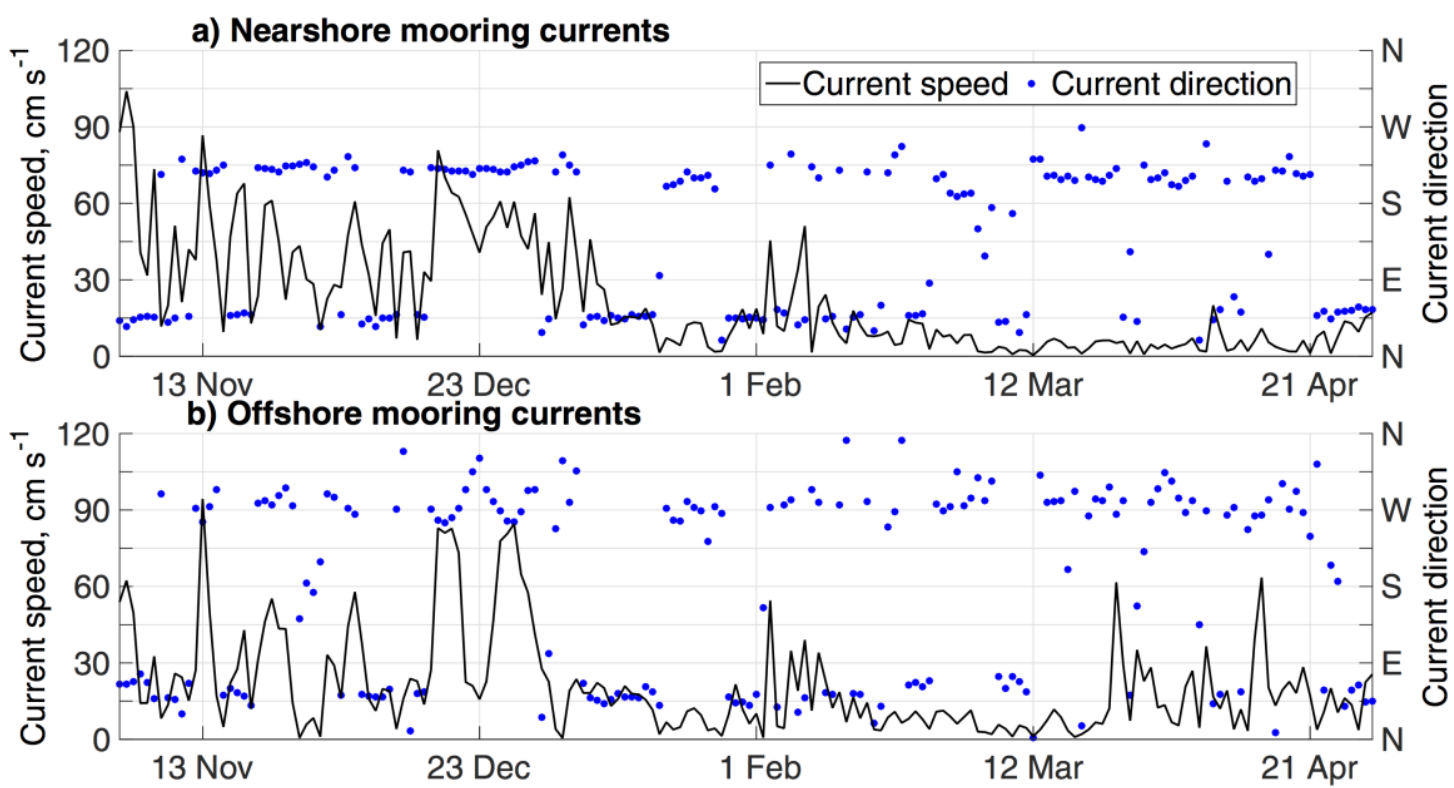
"Surface water mass composition changes captured by cores of Arctic land-fast sea ice"

-revised manuscript submitted to Continental Shelf Research

Table 1:

Derived effective fractionation coefficients and measured $\delta^{18} \mathrm{O}_{\mathrm{i}}$ used to calculate reconstructed $\delta^{18} \mathrm{O}_{\mathrm{w}}$ values shown in Fig. 4 for (a) Core B and (b) Core C.

(a)

\begin{tabular}{|l|l|l|l|l|}
\hline \multicolumn{2}{|l|}{$\begin{array}{l}\text { Derived effective } \\
\text { fractionation } \\
\text { coefficients (2 d.p.) } \\
\text { (\%o) }\end{array}$} & \multicolumn{2}{l|}{$\begin{array}{l}\text { Measured } \delta^{18} \mathrm{O}_{\mathrm{i}}(2 \\
\text { d.p. })(\% 0)\end{array}$} \\
\hline $\begin{array}{l}\text { Depth } \\
(\mathrm{m})\end{array}$ & Minimum & Maximum & Value & Precision \\
\hline $\begin{array}{l}0.15- \\
0.20\end{array}$ & 1.86 & 1.89 & -0.66 & 0.05 \\
\hline $\begin{array}{l}0.20- \\
0.25\end{array}$ & 1.89 & 1.90 & -0.63 & 0.05 \\
\hline $\begin{array}{l}0.25- \\
0.30\end{array}$ & 1.85 & 1.91 & -0.93 & 0.05 \\
\hline $\begin{array}{l}0.30- \\
0.35\end{array}$ & 1.87 & 1.88 & -0.87 & 0.05 \\
\hline $\begin{array}{l}0.35- \\
0.40\end{array}$ & 1.89 & 1.90 & -0.04 & 0.05 \\
\hline $\begin{array}{l}0.40- \\
0.45\end{array}$ & 1.90 & 1.92 & -0.59 & 0.05 \\
\hline $\begin{array}{l}0.45- \\
0.50\end{array}$ & 1.93 & 1.94 & -0.38 & 0.05 \\
\hline $\begin{array}{l}0.50- \\
0.55\end{array}$ & 1.85 & 1.98 & -0.40 & 0.05 \\
\hline $\begin{array}{l}0.55- \\
0.60\end{array}$ & 1.99 & 2.13 & 0.12 & 0.05 \\
\hline $\begin{array}{l}0.60- \\
0.65\end{array}$ & 2.11 & 2.20 & 0.43 & 0.05 \\
\hline $\begin{array}{l}0.65- \\
0.70\end{array}$ & 2.04 & 2.12 & 0.37 & 0.05 \\
\hline $\begin{array}{l}0.70- \\
0.75\end{array}$ & 2.00 & 2.08 & 0.21 & 0.05 \\
\hline $\begin{array}{l}0.75- \\
0.80\end{array}$ & 2.03 & 2.16 & -0.27 & 0.05 \\
\hline $\begin{array}{l}0.80- \\
0.85\end{array}$ & 2.10 & 2.18 & -0.81 & 0.05 \\
\hline $\begin{array}{l}0.85- \\
0.90\end{array}$ & 2.12 & 2.21 & -0.44 & 0.05 \\
\hline $\begin{array}{l}0.90- \\
0.95\end{array}$ & 2.12 & 2.23 & 0.14 & 0.05 \\
\hline $\begin{array}{l}0.95- \\
1.00\end{array}$ & 2.14 & 2.28 & 0.42 & 0.05 \\
\hline $1.00-$ & 2.13 & 2.21 & 0.11 & 0.05 \\
\hline
\end{tabular}


"Surface water mass composition changes captured by cores of Arctic land-fast sea ice" -revised manuscript submitted to Continental Shelf Research

\begin{tabular}{|l|l|l|l|l|}
\hline 1.05 & & & & \\
\hline $\begin{array}{l}1.05- \\
1.10\end{array}$ & 2.08 & 2.17 & -0.49 & 0.05 \\
\hline $\begin{array}{l}1.10- \\
1.15\end{array}$ & 2.08 & 2.39 & -0.95 & 0.05 \\
\hline $\begin{array}{l}1.15- \\
1.20\end{array}$ & 2.16 & 2.52 & -0.77 & 0.05 \\
\hline $\begin{array}{l}1.20- \\
1.25\end{array}$ & 2.36 & 2.50 & -0.44 & 0.05 \\
\hline $\begin{array}{l}1.25- \\
1.30\end{array}$ & 2.33 & 2.44 & -0.48 & 0.05 \\
\hline $\begin{array}{l}1.30- \\
1.35\end{array}$ & 2.28 & 2.37 & -0.83 & 0.05 \\
\hline $\begin{array}{l}1.35- \\
1.40\end{array}$ & 2.26 & 2.37 & -0.95 & 0.05 \\
\hline $\begin{array}{l}1.40- \\
1.45\end{array}$ & 2.29 & 2.41 & -0.89 & 0.05 \\
\hline $\begin{array}{l}1.45- \\
1.50\end{array}$ & 2.29 & 2.52 & -1.09 & 0.05 \\
\hline $\begin{array}{l}1.50- \\
1.55\end{array}$ & 2.32 & 2.46 & -1.11 & 0.05 \\
\hline
\end{tabular}

(b)

\begin{tabular}{|l|l|l|l|l|}
\hline & $\begin{array}{l}\text { Derived effective } \\
\text { fractionation } \\
\text { coefficients (\%o) }\end{array}$ & \multicolumn{2}{l|}{ Measured $\delta^{18} \mathrm{O}_{\mathrm{i}}(\% 0)$} \\
\hline $\begin{array}{l}\text { Depth } \\
(\mathrm{m})\end{array}$ & Minimum & Maximum & Value & Precision \\
\hline $\begin{array}{l}0.15- \\
0.20\end{array}$ & 1.89 & 1.91 & -0.86 & 0.06 \\
\hline $\begin{array}{l}0.20- \\
0.25\end{array}$ & 1.91 & 1.93 & -1.01 & 0.06 \\
\hline $\begin{array}{l}0.25- \\
0.30\end{array}$ & 1.93 & 1.94 & -1.09 & 0.06 \\
\hline $\begin{array}{l}0.30- \\
0.35\end{array}$ & 1.84 & 1.92 & -0.83 & 0.06 \\
\hline $\begin{array}{l}0.35- \\
0.40\end{array}$ & 1.82 & 1.92 & -0.45 & 0.06 \\
\hline $\begin{array}{l}0.40- \\
0.45\end{array}$ & 1.90 & 1.93 & -0.23 & 0.06 \\
\hline $\begin{array}{l}0.45- \\
0.50\end{array}$ & 1.89 & 1.91 & 0.06 & 0.06 \\
\hline $\begin{array}{l}0.50- \\
0.55\end{array}$ & 1.90 & 1.92 & 0.04 & 0.06 \\
\hline $0.55-$ & 1.92 & 1.93 & -0.45 & 0.06 \\
0.60 & & & & \\
\hline
\end{tabular}


"Surface water mass composition changes captured by cores of Arctic land-fast sea ice" -revised manuscript submitted to Continental Shelf Research

\begin{tabular}{|l|l|l|l|l|}
\hline $\begin{array}{l}0.60- \\
0.65\end{array}$ & 1.84 & 1.93 & -1.05 & 0.06 \\
\hline $\begin{array}{l}0.65- \\
0.70\end{array}$ & 1.85 & 1.88 & -1.20 & 0.06 \\
\hline $\begin{array}{l}0.70- \\
0.75\end{array}$ & 1.90 & 1.93 & -1.01 & 0.06 \\
\hline $\begin{array}{l}0.75- \\
0.80\end{array}$ & 1.88 & 1.92 & -0.98 & 0.06 \\
\hline $\begin{array}{l}0.80- \\
0.85\end{array}$ & 1.86 & 1.88 & -1.03 & 0.06 \\
\hline $\begin{array}{l}0.85- \\
0.90\end{array}$ & 1.89 & 1.95 & -1.37 & 0.06 \\
\hline $\begin{array}{l}0.90- \\
0.95\end{array}$ & 1.96 & 1.98 & -1.37 & 0.06 \\
\hline $\begin{array}{l}0.95- \\
1.00\end{array}$ & 1.97 & 1.99 & -1.33 & 0.06 \\
\hline $\begin{array}{l}1.00- \\
1.05\end{array}$ & 1.99 & 2.06 & -1.47 & 0.06 \\
\hline $\begin{array}{l}1.05- \\
1.07\end{array}$ & 2.07 & 2.17 & -1.58 & 0.06 \\
\hline
\end{tabular}


"Surface water mass composition changes captured by cores of Arctic land-fast sea ice"

-revised manuscript submitted to Continental Shelf Research

Table 2:

Mid-point values and half "height" of the reconstructed $\delta^{18} \mathrm{O}_{\mathrm{w}}$ box (\%o) with depth for Fig. 4 results for (a) Core B and (b) Core C.

(a) Core B

\begin{tabular}{|c|c|c|}
\hline Depth (m) & $\begin{array}{l}\text { Reconstructed } \delta^{18} \mathrm{O}_{\mathrm{w}} \\
(\% \text { ) }(2 \text { d.p. })\end{array}$ & $\begin{array}{l}\text { Half "height" of the } \\
\text { reconstructed } \delta^{18} \mathrm{O}_{\mathrm{w}} \\
\text { box }(\% 0)(2 \text { d.p. })\end{array}$ \\
\hline $0.15-0.20$ & -2.54 & 0.06 \\
\hline $0.20-0.25$ & -2.52 & 0.05 \\
\hline $0.25-0.30$ & -2.81 & 0.08 \\
\hline $0.30-0.35$ & -2.74 & 0.05 \\
\hline $0.35-0.40$ & -1.93 & 0.06 \\
\hline $0.40-0.45$ & -2.50 & 0.06 \\
\hline $0.45-0.50$ & -2.31 & 0.05 \\
\hline $0.50-0.55$ & -2.31 & 0.12 \\
\hline $0.55-0.60$ & -1.94 & 0.12 \\
\hline $0.60-0.65$ & -1.73 & 0.09 \\
\hline $0.65-0.70$ & -1.71 & 0.09 \\
\hline $0.70-0.75$ & -1.83 & 0.09 \\
\hline $0.75-0.80$ & -2.36 & 0.11 \\
\hline $0.80-0.85$ & -2.95 & 0.09 \\
\hline $0.85-0.90$ & -2.60 & 0.09 \\
\hline $0.90-0.95$ & -2.04 & 0.10 \\
\hline $0.95-1.00$ & -1.79 & 0.12 \\
\hline $1.00-1.05$ & -2.06 & 0.09 \\
\hline $1.05-1.10$ & -2.61 & 0.09 \\
\hline $1.10-1.15$ & -3.19 & 0.21 \\
\hline $1.15-1.20$ & -3.11 & 0.23 \\
\hline $1.20-1.25$ & -2.87 & 0.12 \\
\hline $1.25-1.30$ & -2.87 & 0.11 \\
\hline $1.30-1.35$ & -3.15 & 0.10 \\
\hline $1.35-1.40$ & -3.26 & 0.11 \\
\hline $1.40-1.45$ & -3.25 & 0.11 \\
\hline $1.45-1.50$ & -3.49 & 0.16 \\
\hline $1.50-1.55$ & -3.51 & 0.12 \\
\hline
\end{tabular}


"Surface water mass composition changes captured by cores of Arctic land-fast sea ice"

-revised manuscript submitted to Continental Shelf Research

(b) Core C

\begin{tabular}{|c|c|c|}
\hline Depth (m) & $\begin{array}{l}\text { Reconstructed } \delta^{18} \mathrm{O}_{\mathrm{w}} \\
(\% \text { ) }(2 \text { d.p. })\end{array}$ & $\begin{array}{l}\text { Half "height" of the } \\
\text { reconstructed } \delta^{18} \mathrm{O}_{\mathrm{w}} \\
\text { box }(\% \text { o })(2 \text { d.p. })\end{array}$ \\
\hline $0.15-0.20$ & -2.77 & 0.07 \\
\hline $0.20-0.25$ & -2.93 & 0.07 \\
\hline $0.25-0.30$ & -3.02 & 0.07 \\
\hline $0.30-0.35$ & -2.71 & 0.10 \\
\hline $0.35-0.40$ & -2.32 & 0.11 \\
\hline $0.40-0.45$ & -2.14 & 0.07 \\
\hline $0.45-0.50$ & -1.84 & 0.07 \\
\hline $0.50-0.55$ & -1.86 & 0.07 \\
\hline $0.55-0.60$ & -2.38 & 0.07 \\
\hline $0.60-0.65$ & -2.93 & 0.11 \\
\hline $0.65-0.70$ & -3.07 & 0.08 \\
\hline $0.70-0.75$ & -2.92 & 0.08 \\
\hline $0.75-0.80$ & -2.88 & 0.08 \\
\hline $0.80-0.85$ & -2.91 & 0.07 \\
\hline $0.85-0.90$ & -3.28 & 0.09 \\
\hline $0.90-0.95$ & -3.34 & 0.07 \\
\hline $0.95-1.00$ & -3.30 & 0.07 \\
\hline $1.00-1.05$ & -3.49 & 0.09 \\
\hline $1.05-1.07$ & -3.70 & 0.11 \\
\hline
\end{tabular}

